\title{
Circulating Nucleic Acid-Based Biomarkers of Type 2 Diabetes
}

\author{
Felipe Padilla-Martinez ${ }^{1,+} \oplus$, Gladys Wojciechowska ${ }^{1, *,+}+$, Lukasz Szczerbinski ${ }^{1,2}\left(\mathbb{C}\right.$ and Adam Kretowski ${ }^{1,2}$ (D) \\ 1 Clinical Research Centre, Medical University of Bialystok, 15276 Bialystok, Poland; \\ luis.padilla@umb.edu.pl (F.P.-M.); lukasz.szczerbinski@umb.edu.pl (L.S.); adam.kretowski@umb.edu.pl (A.K.) \\ 2 Department of Endocrinology, Diabetology and Internal Medicine, Medical University of Bialystok, \\ 15276 Bialystok, Poland \\ * Correspondence: gladys.wojciechowska@umb.edu.pl \\ + These authors contributed equally to this work.
}

check for updates

Citation: Padilla-Martinez, F.; Wojciechowska, G.; Szczerbinski, L. Kretowski, A. Circulating Nucleic Acid-Based Biomarkers of Type 2 Diabetes. Int. J. Mol. Sci. 2022, 23, 295. https://doi.org/10.3390/ijms23010295

Academic Editors: Elisabetta Ferretti, Zein Mersini Besharat and Agnese Po

Received: 10 December 2021

Accepted: 26 December 2021

Published: 28 December 2021

Publisher's Note: MDPI stays neutral with regard to jurisdictional claims in published maps and institutional affiliations.

Copyright: (C) 2021 by the authors. Licensee MDPI, Basel, Switzerland. This article is an open access article distributed under the terms and conditions of the Creative Commons Attribution (CC BY) license (https:// creativecommons.org/licenses/by/ $4.0 /)$.

\begin{abstract}
Type 2 diabetes (T2D) is a deficiency in how the body regulates glucose. Uncontrolled T2D will result in chronic high blood sugar levels, eventually resulting in T2D complications. These complications, such as kidney, eye, and nerve damage, are even harder to treat. Identifying individuals at high risk of developing T2D and its complications is essential for early prevention and treatment. Numerous studies have been done to identify biomarkers for T2D diagnosis and prognosis. This review focuses on recent T2D biomarker studies based on circulating nucleic acids using different omics technologies: genomics, transcriptomics, and epigenomics. Omics studies have profiled biomarker candidates from blood, urine, and other non-invasive samples. Despite methodological differences, several candidate biomarkers were reported for the risk and diagnosis of T2D, the prognosis of T2D complications, and pharmacodynamics of T2D treatments. Future studies should be done to validate the findings in larger samples and blood-based biomarkers in non-invasive samples to support the realization of precision medicine for T2D.
\end{abstract}

Keywords: biomarkers; genomics; transcriptomics; epigenomics; type 2 diabetes; nucleic acid

\section{Introduction}

Type 2 diabetes (T2D) remains a significant clinical burden worldwide. Approximately 462 million individuals (6.28\% of the world's population) lived with T2D in 2017, and the prevalence continues to rise [1]. Better screening, diagnosis, and treatment approaches are needed to combat T2D. Early screening would ensure the timely implementation of lifestyle interventions for those at risk of developing T2D [2]. Early diagnosis is substantially beneficial for T2D patients. Even though T2D incidence peaks at age 55-59, many develop the disease at earlier ages and are often undiagnosed for years [1,3]. Early diagnosis would allow early treatment and prevent T2D complications, which are more challenging to treat [4]. Personalized T2D management, where drug choice is based on each patient's characteristics, would maximize glycemic control efficiency and minimize side effects [5].

These goals can be achieved by identifying T2D biomarkers for each purpose. A biomarker is a biological observation that predicts an important endpoint or intermediate outcome in the clinical diagnosis [6]. The Biomarkers, EndpointS, and other Tools (BEST) glossary from the US National Institutes of Health (NIH) [7] defines seven biomarker categories: susceptibility/risk [8], diagnostic [9], monitoring [10], prognostic [11], predictive [12], pharmacodynamic/response [13], and safety [14] (Table 1).

Numerous studies have been conducted to identify T2D biomarkers. Several reviews have summarized genetic and non-genetic susceptibility/risk biomarkers for developing T2D [15-17]. Another review summarized omics-based biomarkers for diagnosing different types of diabetes and included non-invasive biomarkers from urine and saliva [18]. Research on omics-based and non-invasive T2D biomarkers has increased in recent years and proposed potential novel biomarkers. So, this review aims to summarize candidate 
human T2D biomarkers from a genomic, transcriptomic, and epigenomic perspective. We looked into T2D studies reporting all biomarkers categories, including risk and diagnostic biomarkers from blood, urine, and saliva samples. The gene names and symbols are listed in Table S1 (see Supplementary Materials).

Table 1. Definitions of biomarkers and potential applications.

\begin{tabular}{|c|c|c|}
\hline Type of Biomarker & BEST Definition & Application/Example \\
\hline Susceptibility/risk & $\begin{array}{l}\text { A biomarker that indicates the potential for } \\
\text { developing a disease or medical condition in } \\
\text { an individual who does not currently have } \\
\text { clinically apparent disease or } \\
\text { medical condition }\end{array}$ & $\begin{array}{l}\text { BRCA1/2 mutations can be used to } \\
\text { identify individuals with a predisposition } \\
\text { to develop breast cancer }\end{array}$ \\
\hline Diagnostic & $\begin{array}{l}\text { A biomarker to detect or confirm the } \\
\text { presence of a disease or condition of interest } \\
\text { or to identify individuals with a subtype of } \\
\text { the disease }\end{array}$ & $\begin{array}{c}\text { HbA1c can be used to identify patients } \\
\text { with T2DM }\end{array}$ \\
\hline Monitoring & $\begin{array}{l}\text { A biomarker measured repeatedly for } \\
\text { assessing disease status or medical condition } \\
\text { or for evidence of exposure to (or effect of) a } \\
\text { medical product or an environmental agent }\end{array}$ & $\begin{array}{l}\text { Hepatitis C virus or HIV RNA may be } \\
\text { measured repeatedly to monitor } \\
\text { treatment response }\end{array}$ \\
\hline Prognostic & $\begin{array}{l}\text { A biomarker to identify likelihood of a } \\
\text { clinical event, disease recurrence, or } \\
\text { progression in patients who have the disease } \\
\text { or medical condition of interest }\end{array}$ & $\begin{array}{l}\text { BRCA1/2 mutations can evaluate the } \\
\text { likelihood of second breast cancer. }\end{array}$ \\
\hline Predictive & $\begin{array}{l}\text { A biomarker used to identify individuals } \\
\text { who are more likely than similar individuals } \\
\text { without the biomarker to experience a } \\
\text { favorable or unfavorable effect from } \\
\text { exposure to a medical product or an } \\
\text { environmental agent }\end{array}$ & $\begin{array}{c}\text { BRCA1/2 mutations can identify ovarian } \\
\text { cancer patients likely to respond to } \\
\text { PARP inhibitors }\end{array}$ \\
\hline Pharmacodynamic/response & $\begin{array}{l}\text { A biomarker used to show that a biological } \\
\text { response has occurred in an individual who } \\
\text { has been exposed to a medical product or an } \\
\text { environmental agent }\end{array}$ & $\begin{array}{l}\text { HbA1c may be used to assess diabetes } \\
\text { control after treatment }\end{array}$ \\
\hline Safety & $\begin{array}{l}\text { A biomarker measured before or after an } \\
\text { exposure to a medical product or an } \\
\text { environmental agent to indicate the } \\
\text { likelihood, presence, or extent of toxicity as } \\
\text { an adverse effect }\end{array}$ & $\begin{array}{l}\text { Neutrophil count can be used to adjust } \\
\text { dose for patients on } \\
\text { cytotoxic chemotherapy. }\end{array}$ \\
\hline
\end{tabular}

\section{Genomics Biomarkers for T2D}

The science of genomes, or "genomics", studies the structure, expression, and function of the whole DNA sequences of an organism. It has rapidly expanded towards a more functional level, studying the evolution, mapping, and editing of genomes [19]. Genomics analyzes genetic variants, such as single nucleotide polymorphisms (SNPs) and chromosomal abnormalities related to medical conditions [18]. T2D genomics studies used TaqMan qPCR assays, next-generation sequencing, and DNA microarray technologies.

\subsection{Blood}

Among all sample types, blood biomarkers represent the most accessible and most studied, given their properties and ease of collection in clinical practice [20]. A wide variety of T2D-related biomarkers in blood using genomic data has been reported (Table 2).

Heritability is a strong predictor of T2D (26-69\% depending on the age of onset), thus motivating the search for genetic predictors of T2D [21]. One way to translate genetic data to a predictive measure of disease susceptibility is to add the risk effects of loci into a polygenic 
risk score (PRS) [22,23]. Prediction accuracy of a PRS is often assessed by measuring the area under the receiver operating characteristic curve (AUC). The AUC compares the rates of true positives and false positives, accounting for the overall performance of predictive models [24]. The first PRS for T2D was developed in 2006 using three genetic variants: KCNJ11, PPARG, and TCF7L2 [25]. Two years later, three PRSs were developed using more SNPs. Two of them had 18 SNPs, and the third one had 11 . Their AUC was $78 \%, 90 \%$, and 74\%, respectively [26-28]. In 2014, a 62-SNP PRS was developed using the DIAGRAMv3 Panel of Genes [29], with an AUC of 90\% [30]. In 2016, Chikowore analyzed a South African population; a PRS using only four SNPs was created, taking into account sex, age, BMI, and systolic blood pressure as clinical risk factors, with an AUC of $66.5 \%$. This research was the first to develop PRS in non-caucasian ethnic group with a high sensitivity and specificity [31]. Recent PRS models include many more SNPs, thanks to the larger genome-wide association studies (GWAS) in recent years. Furthermore, in 2016, Lall and colleagues published a PRS using 1000 SNPs from the DIAGRAM Panel of Genes, with an AUC of $77 \%$ [32].

Besides using SNPs in a PRS, some studies demonstrate other ways of utilizing SNPs as risk biomarkers. Ding and colleagues demonstrate that a low circulating level of sex hormone-binding globulin is a potential risk biomarker of T2D. Nevertheless, the clinical use of $S H B G$ needs further examination [33]. In 2015, a study showed that endogenous bilirubin and the associated SNP, rs6742078 in the UGT1A1 locus, are associated with the risk of T2D, making it a candidate as a risk biomarker [34]. Two years later, Wheeler identified 60 common genetic variants associated with $\mathrm{HbA1c}$ using genome-wide association metaanalyses from 82 European, African, East Asian, and South Asian ancestry cohorts. They found out that a G6PD deficiency can be clinically silent until illness strikes. Therefore, screening with direct glucose measurements in people with G6PD deficiency may be helpful as a risk predictor of $\mathrm{T} 2 \mathrm{D}$ [35].

One of the first studies researching predictor biomarkers of T2D was done in 2010. In the study, the levels of plasma GAPDH, representing total cell-free DNA, were measured. The levels of cell-free GAPDH were significantly higher in the plasma samples of T2D diabetic patients, becoming a biomarker candidate [36]. The most recent study was done in 2019, where they assessed the potential role of mitochondria in T2D by analyzing bloodbased indices of mitochondrial DNA copy number (mtDNACN) and cell-free mitochondrial DNA (CFmtDNA). As a result, they found a significant locus in the LRRK2/MUC19 region, indicating that mitochondrial dysfunction is intimately linked to T2D prediction, therefore being a candidate biomarker [37].

\subsection{Urine}

Urine samples have several advantages above blood: the collection is easy and noninvasive, and the samples are available in large volumes. Anyone can collect urine samples, unlike blood samples which require clinical personnel [38]. Urine is not generally used for DNA analysis because the extracted DNA is less stable than blood. So, most T2D genomics studies collect blood and urine samples to study the associations between blood genetic variants and urine proteins (Table 3). However, recent studies have improved DNA extraction from urine [39]. One recent T2D study reported associations between mitochondrial DNA (mtDNA) from urine samples with T2D, demonstrating the possibility of urine-extracted DNA as biomarkers for T2D [40]. 
Table 2. Genomics biomarkers from blood samples for T2D.

\begin{tabular}{|c|c|c|c|c|}
\hline Sample Type & Profiling Method & $\begin{array}{c}\text { Sample Size } \\
\text { (Controls, T2D, Other) }\end{array}$ & Biomarker & Ref. \\
\hline Blood & Microarray & 178,178 & FTO, PSMD6, SLC44A3, C2CD4B & [31] \\
\hline Blood & GWAS, microarray & $33,241^{\wedge}$ & G6PD & [35] \\
\hline Blood & qRT-PCR & 3669,2409 & KCNK11, PPARG, TCF7L2 & [25] \\
\hline Blood & qRT-PCR & $23,23,6^{* *}$ & LRRK2/MUC19 (mtDNACN and CFmtDNA) & [37] \\
\hline Blood & Microarray & $2776^{\wedge}$ & $\begin{array}{c}\text { NOTCH2, BCL11A, THADA, IGF2BP2, PPARG, ADAMTS9, } \\
\text { CDKAL1, VEGFA, JAZF1, SLC3OA8, CDKNA/2B, HHEX, } \\
\text { CDC123, TCF7L2, KCNJ11, INS, DCD, TSPAN8 }\end{array}$ & [27] \\
\hline Blood & Microarray & 9092,1181 & Panel of Genes DIAGRAM & [32] \\
\hline Blood & qRT-PCR, DNA Sequencing & $3471^{\wedge}$ & Panel of Genes DIAGRAMv3 & [30] \\
\hline Blood & qRT-PCR & 2598,2309 & $\begin{array}{l}\text { TCF7L2, KCNJ11, CDKN2A, PPARG, ADAM30, CDKN2B, } \\
\text { IGF2BP2, FTO, CDKAL1, SLC30A8, TSPAN8, CDC123, } \\
\text { WFS1, TCF2, ADAMTS9, HHEX-IDE, THADA, JAZF1 }\end{array}$ & [26] \\
\hline Blood & qRT-PCR & $18,831^{\wedge}$ & $\begin{array}{l}\text { TCF7L2, PPARG, FTO, KCNJ11, NOTCH2, WFS1, CDKAL1, } \\
\text { IGF2BP2, SLC30A8, JAZF1, and HHEX }\end{array}$ & [28] \\
\hline Blood & Microarray & 3171,210 & UGT1A1 & [34] \\
\hline Blood Plasma & qRT-PCR & $20,25,25 * *$ & GAPDH & [36] \\
\hline Blood Plasma & qRT-PCR & 359,359 & SHBG & [33] \\
\hline
\end{tabular}

** T2D patients with complications or comorbidities; ^ cohort study.

Table 3. Genomics biomarkers from urine samples for T2D.

\begin{tabular}{ccccc}
\hline Sample Type & Profiling Method & $\begin{array}{c}\text { Sample Size } \\
\text { (Controls, T2D, Other) }\end{array}$ & Biomarker & Ref. \\
\hline Blood (plasma or serum) and urine & qRT-PCR & $4668,0,2290 * *$ & Urine albumin-to-creatinine ratio and \\
WFS1 (rs10010131) & [41] \\
\hline Blood (plasma) and urine & qRT-PCR & $0,290,285^{* *}$ & Urine albumin and PGC-1 $\alpha$ (rs8192678) & [42] \\
\hline Blood and urine & qRT-PCR & $35,0,42^{* *}$ & Urine creatinine ratio with mtDNA & [40] \\
\hline
\end{tabular}

** T2D patients with complications or comorbidities.

All T2D genomics urine studies looked into diabetic kidney disease (DKD), including diabetic nephropathy (DN) (Table 3). DKD is one of the significant complications of T2D and is the leading cause of end-stage renal failure. About one-third of diabetes patients will develop kidney disease, so identifying DKD biomarkers is essential for early prevention [43]. T2D studies on urinary biomarkers usually include patients with normo-, micro-, and macroalbuminuria.

Two studies found associations between SNPs measured from blood samples with urine proteins. A prospective study reported that rs10010131 in the WFS1 gene is associated with a higher estimated glomerular filtration rate (eGFR) in T2D patients with increased albuminuria. This result suggests a potential role of WFS1 as a risk biomarker of T2D and its kidney complications [41]. The second study examined the association between urine albumin and rs 8192678 in the PGC- $1 \alpha$ gene, a genotype previously related to nephropathy in T2D patients. The genotype was found to be associated with a $70 \%$ increase in urine albumin excretion in T2D patients with proteinuria compared to T2D patients with normoalbuminuria, making PGC-1 $\alpha$ a candidate prognostic biomarker [42].

The only T2D study on urine-extracted DNA looked into mtDNA from healthy controls and T2D patients with and without proteinuria. Plasma and urine mtDNA content significantly differed between T2D patients and controls, where a reduction in plasma mtDNA content and increased urinary mtDNA/creatinine ratio were observed. The study did not report significant differences between T2D patients with and without proteinuria. So, the findings suggest that mtDNA could be a diagnostic biomarker of T2D [40].

\subsection{Other Non-Invasive Biomarkers and the Use of Metagenomics}

Saliva is another non-invasive sample to research biomarkers using genomic technology. Saliva-extracted DNA has comparable quantity and quality with blood, making saliva 
a suitable source of DNA for genetic studies. So, unlike urine, saliva has been used in large genetic epidemiological and metabolic studies [44]. However, there are no T2D studies that profile human DNA from saliva samples. One study profiled polymorphisms for CHGA from peripheral blood leukocytes and measured CHGA concentration in saliva (Table 4). The study found associations between two polymorphisms (rs9658635 in the promoter region and Glu264Asp in exon 6) with higher salivary CHGA production [45]. It remains to be seen whether these DNA biomarkers can also be detected in saliva samples.

In addition to human DNA, microbial DNA can also be extracted from saliva. Metagenomics studies the DNA sequences of an entire community of microorganisms [46]. The metagenomics studies aim to find associations between microbial profiles and human phenotypes. The technologies most frequently used in this area are 16S rRNA sequencing and whole-genome sequencing [18]. A recent study reported a higher relative abundance of Bulleidia, Ruminococcaceae, and Helicobacter pylori in T2D patients compared to healthy controls. However, the study was done in only nine T2D patients, so future studies are needed to confirm the findings [47] (Table 4).

Table 4. Genomics and metagenomics biomarkers from saliva and fecal samples for T2D.

\begin{tabular}{|c|c|c|c|c|}
\hline Sample Type & Profiling Method & $\begin{array}{c}\text { Sample Size } \\
\text { (Controls, T2D, Other) }\end{array}$ & Biomarker & Ref. \\
\hline Fecal & $16 S$ rRNA sequencing & 20,20 & $\begin{array}{c}\text { Gut microbiome (Ruminococcaceae, } \\
\text { Lachnospiraceae, and Enterobacteriaceae) }\end{array}$ & [48] \\
\hline Fecal & $16 S$ rRNA sequencing & 10,10 & $\begin{array}{c}\text { Gut microbiome } \\
\text { (Akkermansia muciniphila) }\end{array}$ & [49] \\
\hline Fecal & $16 \mathrm{~S}$ rRNA sequencing & $1427,122,1305 \#$ & $\begin{array}{c}\text { Gut microbiome (Bacterial sepecies with } \\
\text { enriched ARG) }\end{array}$ & {$[50]$} \\
\hline Fecal & 16S rRNA sequencing & $214,48,17 \$, 151 *$ & $\begin{array}{c}\text { Gut microbiome (Escherichia, Veillonella, } \\
\text { Blautia and Anaerostipes) }\end{array}$ & [51] \\
\hline Fecal & $16 \mathrm{~S}$ rRNA sequencing & $55,0,71 \#, 38$ ** & Gut microbiome (Ruminococcus torques) & {$[52]$} \\
\hline Saliva & 16S rRNA sequencing & $27,9,31 \#, 20 \$, 46^{* *}$ & $\begin{array}{l}\text { Oral Microbiome (Bulleidia, } \\
\text { Ruminococcaceae, and Helicobacter pylori) }\end{array}$ & [47] \\
\hline
\end{tabular}

* Pre-diabetes; ${ }^{* *}$ T2D patients with complications or comorbidities; \$ T2D patients with treatment; \# non-T2D subjects with comorbidities.

T2D genetic studies have also been done using fecal samples. The genetic material from fecal samples is mostly bacterial, although human DNA can be detected in small amounts. There are efforts to improve human DNA extraction from stool samples, but significant challenges still exist for its use in population studies [53]. Therefore, all T2D studies with fecal samples are metagenomics studies (Table 4).

In 2016, a study showed evidence that the inflammation of the gut increased the values of biomarkers related to T2D. Microbial signatures of Akkermansia muciniphila demonstrate the existence of inflammation, increasing the risk of T2D before they are reflected by clinical markers [49]. Other metagenomics studies identified Akkermansia muciniphila, Ruminococcus torques, Ruminococcaceae, Lachnospiraceae, and Enterobacteriaceae to be associated with T2D [54-57]. In a critically high-risk population, a recent study demonstrated associations between Escherichia, Veillonella, Blautia and Anaerostipes with T2D [51]. Another study looked into the abundance of antibiotic resistance genes (ARG) in fecal microbiome profiles. The study found ARG enrichment in T2D patients, which could be potential biomarkers of T2D [50]. It remains to be seen if these T2D-associated changes in the gut contribute to T2D pathogenesis.

\section{Transcriptomics Biomarkers of T2D}

Transcriptomics is the comprehensive study of total gene expression levels in a cell or organism [58,59]. Most T2D messenger RNA (mRNA) research does not qualify this definition, as most studies profiled specific genes related to the study population. Nevertheless, the studies have identified potential mRNA biomarkers of T2D. The most common 
profiling method for T2D mRNA studies is targeted quantitative reverse-transcription PCR, where isolated RNAs are reverse transcribed to CDNA, then the expression levels of specific genes are measured quantitatively using qPCR. A few more recent T2D studies use microarray and RNA sequencing to measure many genes, but only in a small number of samples. Then, the top differentially expressed genes are validated using qRT-PCR in a larger number of samples. Currently, most T2D mRNA studies have been conducted with blood, but there is an increasing number of studies on non-invasive samples, such as urine and saliva.

\subsection{Blood}

Blood mRNA T2D studies have profiled gene expression in many sample types, from whole blood samples to leukocytes (Table 5). Only one study compared gene expression levels between two sample types: serum and urine [60]. There is little consensus on mRNA biomarkers because all studies selected genes related to their study population.

Blood mRNA studies on T2D patients without complications have identified elevated levels of inflammatory and senescence markers, as well as metabolically relevant receptor genes [61-64]. Plasma NF- $k B$ expression levels were increased in pre-diabetic patients and further increased in T2D patients [62], suggesting that NF- $k B$ can be a biomarker of early T2D diagnosis. In contrast, blood leptin mRNA levels were reduced in T2D patients compared to non-diabetic controls [65]. The discriminatory power of leptin mRNA was comparable to fasting blood glucose and $\mathrm{HbA} 1 \mathrm{c}$ in distinguishing T2D patients and non-diabetic controls (AUROC $=0.95,95 \%$ CI: 0.89-0.98) [65].

Studies on T2D patients with complications have focused on profiling genes related to T2D, inflammation, or specific diabetic complications [60,66-71]. For example, a study on diabetic kidney disease (DKD) patients selected AEBP1 from a set of estimated glomerular filtration rate (eGFR)-correlated genes [66]. Another study on T2D patients with bone mass reduction or osteoporosis profiled BSP mRNA, a marker of bone metabolism [71]. The overall findings are increased inflammation and reduced expression of protective genes in patients with T2D complications.

One study identified a circulating biomarker for treatment response. A clinical trial administered placebo or zinc supplementation in overweight T2D patients and profiled SOD1 expression in leukocytes [72]. The mRNA levels were significantly elevated in patients who received supplementation, compared to placebo and levels before treatment, and correlated with serum zinc concentrations. So, blood mRNAs can also be response biomarkers to evaluate treatment in T2D patients. More studies are needed to validate and identify other response biomarkers for T2D patients.

Table 5. Transcriptomics biomarkers from blood samples for T2D.

\begin{tabular}{|c|c|c|c|c|}
\hline Sample Type & Profiling Method & $\begin{array}{c}\text { Sample Size } \\
\text { (Controls, T2D, Other) }\end{array}$ & Biomarker & Ref. \\
\hline Leukocytes & qRT-PCR & $0,35,35 \$$ & SOD1 & [72] \\
\hline Monocytes & qRT-PCR & $30,30,30 * *$ & TLR2, TLR4 & [68] \\
\hline PBMC & qRT-PCR & 30,30 & $\begin{array}{c}\text { GLB1, p16, } p 21, p 53, I L-6, \text { TNF-a, SOCS-3, ERR } \gamma, \\
\text { PPAR- } \gamma, \text { NOD-2, CYP2C9 }\end{array}$ & [61] \\
\hline PBMC & qRT-PCR & 20,20 & TRAF-6, NF-kB, SOCS-3 & [64] \\
\hline Plasma & qRT-PCR & $30,30,30 *$ & $N F-k B$ & [62] \\
\hline Plasma & qRT-PCR & $50,55,35^{* *}$ & Vaspin & [69] \\
\hline Plasma exosomes & qRT-PCR & $10,15,15^{* *}$ & $A E B P 1$ & [66] \\
\hline Platelet & qRT-PCR & $46,43,48 *, 36 * *$ & SFRP4 & [70] \\
\hline Serum & qRT-PCR & $45,45,45 \#, 45^{* *}$ & BSP & [71] \\
\hline Serum & qRT-PCR & $41,33,54$ ** & $T T P, I L-6, I L-8$ & [60] \\
\hline Serum exosome & qRT-PCR & $0,20,24^{* *}$ & VEGF & [67] \\
\hline Whole blood & qRT-PCR & 110,148 & $I L-23, T N F-a, I F N-g$ & [63] \\
\hline Whole blood & qRT-PCR & 32,71 & Leptin & [65] \\
\hline
\end{tabular}

* Pre-diabetes; ${ }^{* *}$ T2D patients with complications or comorbidities; \$ T2D patients with treatment; \# non-T2D subjects with comorbidities. 


\subsection{Urine}

Similar to genetics studies, urinary mRNA studies have compared T2D patients with and without DKD (Table 6). The first study looked into the expression levels of TTP and inflammatory markers IL-6 and IL-18. TTP encodes tristetraprolin, which is an anti-inflammatory protein. A significantly reduced TTP expression level was found in T2D patients, and the levels are further reduced in patients with macroalbuminuria. In contrast, $I L-6$ and $I L-18$ were significantly elevated in T2D patients, especially those with complications [60].

Another study looked into podocyte-associated markers: NPHS1, NPHS2, and PODXL [73]. Renal podocyte injury is pathologically significant in DN progression, so podocyte-associated genes might serve as monitoring biomarkers to evaluate kidney health. Urinary podocyte marker levels were significantly elevated in all T2D patients, including those with complications. Patients with macroalbuminuria had higher podocyte marker levels than normoand microalbuminuria patients. These markers distinguished microalbuminuria patients from those without complications in univariate analyses, with AUCs of 0.685-0.961 [73].

A study with 242 participants used the presence of albuminuria and eGFR to define their study groups [74]. This study evaluated gene expression in urinary exosomes using RNA sequencing and validated eight mRNAs (UMOD, SLC12A1, NDUFB2, OAZ1, PPARGC1A, NFE2L2, CD24, SMAD1) using qRT-PCR. So, this is the first agnostic urinary mRNA study where markers were not selected from previously available knowledge. Among the eight mRNAs, UMOD and SLC12A1 levels were elevated in T2D patients with complications compared to those without complications and healthy controls. Significant increases were also seen in NDUFB2 and OAZ1 in T2D patients without complications compared to healthy controls. The four mRNAs were significantly correlated to $\mathrm{HbA} 1 \mathrm{c} \%$, but only OAZ1 was correlated to T2D duration. A multi-gene signature was also developed using the eight mRNAs and linear discriminant analysis with cross-validation. The classifier distinguished severe DKD patients from T2D with an AUC of 0.90 [74].

Table 6. Transcriptomics biomarkers from urine samples for T2D.

\begin{tabular}{|c|c|c|c|c|}
\hline Sample Type & Profiling Method & $\begin{array}{c}\text { Sample Size } \\
\text { (Controls, T2D, Other) }\end{array}$ & Biomarker & Ref \\
\hline Urinary exosomes & RNA sequencing and qRT-PCR & $41,33,54^{* *}$ & TTP, IL-6, IL-8 & [60] \\
\hline Urine & qRT-PCR & $20,20,40 * *$ & NPHS1, NPHS2, PODXL & [73] \\
\hline Urine & qRT-PCR & $18,29 \#, 166,34$ ** & UMOD, SLC12A1, NDUFB2, OAZ1 & {$[74]$} \\
\hline
\end{tabular}

\subsection{Other Non-Invasive Biomarkers}

Unlike genetic T2D biomarkers, there is limited research for mRNA biomarkers from saliva samples. One study reported differential salivary gene expression from $13 \mathrm{~T} 2 \mathrm{D}$ patients: elevated KRAS, SAT1, SLC13A2, and TMEM72 and reduced EGFR and PSMB2 gene expressions [75]. The six biomarkers were first identified through microarray, then validated in 13 T2D patients and 13 healthy controls. A logistic model with four out of the six salivary biomarkers (KRAS, SAT1, EGRF, and PSMB2) discriminated T2D patients from healthy controls (AUC: $0.917,95 \%$ CI: 0.809-1.000). So, salivary mRNAs are promising T2D biomarkers, but more studies on these samples are needed.

\section{Epigenomics Biomarkers for T2D}

Epigenomics studies the whole gene regulation of an organism or cell, including DNA methylation and microRNAs (miRNAs) [59,76]. Epigenetic factors regulate gene expression without modifying DNA sequence. For example, DNA methylation of CpG islands influences transcription factor binding, resulting in stable silencing of gene transcription [77]. Gene expression can also be regulated post-transcriptionally through miRNAs, which bind to target mRNAs and typically lead to translational repression [78]. The miRNA-mRNA 
interactions can be binary off-switch interactions or tuning interactions in response to an environmental cue [79].

There is growing interest in identifying circulating epigenetic biomarkers for T2D, especially since T2D has a substantial environmental influence, such as sedentary lifestyle and obesity. Identifying risk, predictive, monitoring, and response biomarkers are among the most common research aims in T2D epigenomic studies.

\subsection{Blood}

\subsubsection{DNA Methylation}

All of the T2D DNA methylation blood studies were done on peripheral blood. The bisulfite conversion technologies vary; the most used were: EZ-DNA Methylation Kit from Zymo Research and EpiTect Bisulfite kit from QIAGEN. The DNA methylation technology most used in the studies was Illumina Human-Methylation450 BeadChip, followed by Qiagen PyroMark Pyrosequencing.

The study designs are different; nevertheless, there are CpG sites in specific genes repeated in several DNA methylation studies (Table 7). The T2D biomarkers most studied are CPG sites in the genes ABCG1, TXNIP, SREBF1, and PHOSPHO1. With six [80-85], four $[80,81,84,86]$, three $[80,84,85]$, and two $[80,83]$ studies, respectively. The four methylation sites in those genes are in relevant pathways related to T2D. The gene ABCG1 is involved in cholesterol and phospholipid transport and insulin secretion. DNA methylation at $A B C G 1$ has been associated with fasting insulin and HOMA-IR $[87,88]$. The gene TXNIP is a component of pancreatic $\beta$-cell biology, energy metabolism, and cellular redox regulation. TXNIP downregulation protects against obesity-induced diabetes by preventing $\beta$-cell apoptosis and preserving $\beta$-cell mass $[89,90]$. The gene SREBF1 is activated by insulin and contributes to dyslipidemia and hepatic steatosis that occurs in obesity and T2D [91]. The gene PHOSPHO1 is considered to be an attractive target for cardiovascular therapy. It has been found that DNA methylation at this gene is correlated positively with HDL levels $[83,92]$. The results of these studies open the way for functional studies to define their use as biomarkers of T2D and other metabolic comorbidities.

There are other DNA methylation studies of $\mathrm{CpG}$ sites that were reported. There were five publications during the 2010-2013 period, the first one discovered three CpG sites in the gene TFAM [93], the second found one CpG in the gene FTO [94], the third found one CpG site in the gene IGFBP-1 [95], the fourth found seven CpG sites in the gene PRKCZ [96], and the fifth found thirteen CpG sites in the gene TCF7L2 [97]. In 2014, an interesting study showed that lower LINE-1 levels after global DNA methylation were associated with a higher risk of a poor carbohydrate metabolic status. This biomarker could be considered a risk factor of T2D and related metabolic disorders, independent of other established risk factors, therefore having a potential role as a possible biomarker [98]. From 2015 to 2017, another four studies suggested new CpG sites of possible interest for T2D biomarker development. The first one suggested five CpG sites in the gene SLC30A8 [99], the second, one CpG site in the gene TXNIP [100], the third one also one CpG in the gene TXNIP [101], and the fourth one two CpG sites, one in the MSI2 gene, and the other one in the CXXC4 gene [102]. At the end of 2017, Van Otterdijk and colleagues reported a tendency between PEG3 DNA methylation levels in peripheral blood leukocytes in T2D patients, and four CpG loci were differentially methylated between groups of participants. As a result, these loci might serve as biomarkers of T2D, although additional research is required to strengthen these observations further [103]. Previous studies had indicated that the ELOVL5 expression is associated with T2D [104,105]. In 2018, Hwang et al. identified the ELOVL5 gene as a novel epigenetic mark in an epigenome-wide analysis of the blood DNA methylation using T2D-discordant monozygotic twins. The results implied that epigenetic alterations in ELOVL5 demonstrate DNA methylation and RNA expression changes. These provide insights into epigenetic biomarkers for T2D [106]. 
These methylation markers' risk or diagnostic value may be small to justify them as a novel biomarker. Thus, further improvement should include CpG sites showing a higher methylation difference.

Table 7. DNA methylation biomarkers from blood samples for T2D.

\begin{tabular}{|c|c|c|c|c|}
\hline Sample Type & Profiling Method & $\begin{array}{c}\text { Sample Size } \\
\text { (Controls, T2D, Other) }\end{array}$ & Biomarker & Ref. \\
\hline Peripheral blood leukocytes & Pyrosequencing & 11,25 & 4 CpG sites (PEG3) & [103] \\
\hline Whole Blood & EpiTYPER assay & 93,93 & 13 CpG sites (TCF7L2) & [97] \\
\hline Whole Blood & $\begin{array}{l}\text { Methylation-specific } \\
\text { polymerase chain } \\
\text { reaction (MSPCR) }\end{array}$ & 45,77 & 3 CpG sites (TFAM) & {$[93]$} \\
\hline Whole Blood & Pyrosequencing & 441,509 & 5 CpG sites (SLC30A8) & [99] \\
\hline Whole Blood & Microarray & 120,152 & $7 \mathrm{CpG}$ sites $(P R K C Z)$ & [96] \\
\hline Whole Blood & Microarray & 93,30 & $A B C G 1$ and $C C D C 57$ & [82] \\
\hline Whole Blood & Microarray & 6760,306 & $\begin{array}{c}\text { ABCG1, PHOSPHO1, SOCS3, SREBF1, } \\
\text { and TXNIP }\end{array}$ & {$[80]$} \\
\hline Whole Blood & Microarray & 11927,1608 & $\begin{array}{c}\text { ABCG1, PHOSPHO1, SOCS3, SREBF1, } \\
\text { and TXNIP }\end{array}$ & {$[80]$} \\
\hline Whole Blood & Microarray & 129,129 & $\begin{array}{l}\text { cg06500161 (ABCG1) and } \\
\text { cg02650017 (PHOSPHO1) }\end{array}$ & {$[83]$} \\
\hline Whole Blood & DNA sequencing & 176,100 & $\begin{array}{l}\text { cg06500161 (ABCG1) and } \\
\text { cg11024682 (SREBF1) }\end{array}$ & {$[85]$} \\
\hline Whole Blood & Microarray & 11,11 & $\operatorname{cg} 18681426(E L O V L 5)$ & {$[106]$} \\
\hline Whole Blood & Microarray & 835,153 & cg19693031 (TXNIP) & [100] \\
\hline Whole Blood & Microarray & 204,151 & cg19693031 (TXNIP) & {$[101]$} \\
\hline Whole Blood & Microarray & 98,100 & $\begin{array}{c}\text { CpGs (in } A B C G 1, L O X L 2, T X N I P, S L C 1 A 5, \\
\text { and SREBF1) }\end{array}$ & {$[84]$} \\
\hline Whole Blood & Pyrosequencing & 606,710 & FTO & {$[94]$} \\
\hline Whole Blood & Pyrosequencing & 100,240 & $I G F B P-1$ and $I G F B P-7$ & [95] \\
\hline Whole Blood & Pyrosequencing & 100,100 & $\begin{array}{l}\text { Long Interspersed Nucleotide Element } 1 \\
\qquad(L I N E-1)\end{array}$ & {$[98]$} \\
\hline Whole Blood & Microarray & 220,220 & MSI2 and CXXC4 & [102] \\
\hline Whole Blood & Microarray & 457,256 & $\begin{array}{c}\text { TXNIP (cg19693031), C7orf50 (cg04816311), } \\
\text { CPT1A (cg00574958), and } \\
\text { TPM4 (cg07988171) }\end{array}$ & {$[86]$} \\
\hline Whole Blood & Microarray & 676,174 & TXNIP, ABCG1 and SAMD12 & [81] \\
\hline
\end{tabular}

\subsection{2. microRNA}

Most T2D miRNA studies were done on blood samples, predominantly plasma, serum, or exosomes (Table 8). A few studies used whole blood, PBMCs, or endothelial progenitor cells. Almost all studies used qRT-PCR: profiling a large number of miRNAs using PCR panels, targeting a small number of miRNAs, or validating results from microarray, RNA sequencing, or nanostring. Some studies used RNA sequencing without qRT-PCR validation.

Despite the different study designs, there are commonly reported miRNAs. The most studied and promising T2D biomarker is hsa-miR-126. This miRNA is highly enriched in endothelial cells and is important for angiogenesis and wound repair [107]. It is downregulated in T2D patients compared to non-diabetic controls and those with impaired glucose tolerance [62,107-122]. It is also further down-regulated in T2D patients with complications $[111,115,119]$ and increases after six months of treatment (insulin with diet control and exercise) [116]. However, aspirin can affect the plasma hsa-miR-126 profile [123]. So, careful participant selection and interpretation of results are needed for future studies on hsa-miR-126. 
Other miRNAs that were reported in at least four studies are hsa-miR-1225p [120,124-126], hsa-miR-146a [64,120,127-131], hsa-miR-150 [112,131-133], hsa-miR15a [107,112,134-136], hsa-miR-192 [110,131,132,137], hsa-miR-21 [67,107,108,119,138-140], hsamiR-223 [107,112,121,135,141], hsa-miR-29a [112,129,131,142], hsa-miR-375 [112,129,132,143-145], and hsa-miR-9 [112,129,145,146]. However, some of the expression directions are not consistent, possibly due to the differences in study population and sample type.

While most studies used univariate analysis to identify biomarkers, some used multivariate analyses to develop classifiers. For example, a logistic regression model with hsa-miR-148b, hsa-miR-223, hsa-miR-130a, and hsa-miR-19a was able to differentiate T2D patients from those with impaired glucose regulation $(\mathrm{AUC}=0.90,95 \% \mathrm{CI}=0.86-0.94)$. The same model had a similar performance in a validation set of 87 patients with impaired glucose tolerance and 113 T2DM patients ( $\mathrm{AUC}=0.88,95 \% \mathrm{CI}=0.83-0.94$ ) [141]. Polygenic risk scores were also developed to predict T2D complications, using three [138] or five [146] miRNAs. A study on short-term intensive insulin therapy found that a Random Forest predictor containing baseline hsa-miR-145-5p, hsa-miR-29c-3p, and HbA1c could predict responses to therapy better than models with only clinical parameters [137]. These studies further support that circulating blood miRNAs are promising T2D biomarkers. 
Table 8. microRNA biomarkers from blood samples for T2D.

\begin{tabular}{|c|c|c|c|c|}
\hline Sample Type & Profiling Method & Sample Size (Controls, T2D, Other) & Biomarker & Ref. \\
\hline Endothelial progenitor cells & qRT-PCR & 15,15 & $\begin{array}{l}\text { hsa-miR-21, hsa-miR-27a, hsa-miR-27b, } \\
\text { hsa-miR-126, hsa-miR-130 }\end{array}$ & [108] \\
\hline PBMC & qRT-PCR & 20,20 & hsa-miR-146a & [64] \\
\hline Plasma & Microarray and qRT-PCR & $94,112,72 *$ & hsa-let-7b, hsa-miR-142, hsa-miR-144, hsa-miR-29a & [142] \\
\hline Plasma & RNA Sequencing & $0,145,145$ * & $\begin{array}{l}\text { hsa-miR-122-5p, hsa-miR-210-3p, hsa-miR-3200-3p, } \\
\text { hsa-miR-376b-3p, hsa-miR378a-3p, hsa-miR-4532-5p, } \\
\text { hsa-miR-483-5p and hsa-miR-660-3p }\end{array}$ & [125] \\
\hline Plasma & Microarray and qRT-PCR & $50,50,50 *$ & $\begin{array}{l}\text { hsa-miR-1249, hsa-miR-320b, } \\
\text { hsa-miR-572, hsa-miR-6069 }\end{array}$ & [147] \\
\hline Plasma & qRT-PCR & $30,30,30 *$ & hsa-miR-126 & [109] \\
\hline Plasma & qRT-PCR & 20,20 & hsa-miR-126 & [113] \\
\hline Plasma & qRT-PCR & $0,0,36 \$$ & hsa-miR-126 & [123] \\
\hline Plasma & qRT-PCR & $58,69,34 \#, 124 * *$ & hsa-miR-126-3p & [118] \\
\hline Plasma & qRT-PCR & $107,76,117^{* *}$ & hsa-miR-126-3p, hsa-miR-21-5p & [119] \\
\hline Plasma & qRT-PCR & $20,54,46^{* *}$ & hsa-miR-126, hsa-miR-210 & [111] \\
\hline Plasma & qRT-PCR & 80,55 & hsa-miR-126, hsa-miR-26a & [114] \\
\hline Plasma & qRT-PCR & $35,30,10 \#, 18^{* *}$ & $\begin{array}{c}\text { hsa-miR-140-5p, hsa-miR-142-3p, hsa-miR-222, } \\
\text { hsa-miR-423-5p, hsa-miR-192, hsa-miR-125b, } \\
\text { hsa-miR-195, hsa-miR-130b, } \\
\text { hsa-miR-532-5p, hsa-miR-126 }\end{array}$ & [110] \\
\hline Plasma & qRT-PCR & $7,18,17 \$$ & $\begin{array}{l}\text { hsa-miR-140-5p, hsa-miR-222, } \\
\text { hsa-miR-142-3p, hsa-miR-192 }\end{array}$ & [110] \\
\hline Plasma & qRT-PCR & $0,0,24 \$$ & $\begin{array}{l}\text { hsa-miR-145-5p, hsa-miR-29c-3p, hsa-miR-192, } \\
\text { hsa-miR-20a, hsa-let-7b, hsa-miR-802, hsa-miR-34a }\end{array}$ & [137] \\
\hline Plasma & qRT-PCR & $90,58,32 * *$ & hsa-miR-146a & [127] \\
\hline Plasma & qRT-PCR & $9,9,9 *$ & $\begin{array}{l}\text { hsa-miR-148a-3p, hsa-miR-222-3p, hsa-miR-342-3p, } \\
\text { hsa-miR-143-3p, hsa-miR-320b, hsa-miR-320c }\end{array}$ & [148] \\
\hline
\end{tabular}


Table 8. Cont.

\begin{tabular}{|c|c|c|c|c|}
\hline Sample Type & Profiling Method & Sample Size (Controls, T2D, Other) & Biomarker & Ref. \\
\hline Plasma & qRT-PCR & $20,23,26^{* *}$ & hsa-miR-191, hsa-miR-200b & [149] \\
\hline Plasma & qRT-PCR & $50,50,50 \#, 50 * *$ & hsa-miR-195-5p, hsa-miR-130a-3p & [150] \\
\hline Plasma & Microarray, qRT-PCR & $80,9,71^{* *}$ & $\begin{array}{l}\text { hsa-miR-20b, hsa-miR-21, hsa-miR-24, hsa-miR-15a, } \\
\text { hsa-miR-126, hsa-miR-191, hsa-miR-197, hsa-miR-223, } \\
\text { hsa-miR-320, hsa-miR-486, hsa-miR-28-3p }\end{array}$ & [107] \\
\hline Plasma & qRT-PCR & $115,65,124^{* *}$ & hsa-miR-21 & [151] \\
\hline Plasma & qRT-PCR & $285,285,855^{* *}$ & hsa-miR-21, hsa-miR-218, hsa-miR-211 & [138] \\
\hline Plasma & qRT-PCR & 119,33 & hsa-miR-24, hsa-miR-29b, hsa-miR-144 & [152] \\
\hline Plasma & qRT-PCR & $20,91,95$ & hsa-miR-29b, hsa-miR-200b & [153] \\
\hline Plasma & qRT-PCR & 355,107 & $\begin{array}{l}\text { hsa-miR-30a-5p, hsa-miR-150, hsa-miR-9, hsa-miR-15a, } \\
\text { hsa-miR-28-3p, hsa-miR-29a, hsa-miR-103, } \\
\text { hsa-miR-223, hsa-miR-126, hsa-miR-145, } \\
\text { and hsa-miR-375 }\end{array}$ & [154] \\
\hline Plasma & qRT-PCR & 100,100 & hsa-miR-375 & [143] \\
\hline Plasma and plasma exosome & qRT-PCR & $26,26,24 *$ & hsa-miR-15a & [134] \\
\hline Plasma exosome & qRT-PCR & 18,12 & hsa-miR-326, hsa-let-7a, hsa-let-7f & [155] \\
\hline Platelet & qRT-PCR & $46,43,48 \#, 36^{* *}$ & hsa-miR-103b & [70] \\
\hline Serum & RNA sequencing and qRT-PCR & $3,50,29 * *$ & $\begin{array}{l}\text { hsa-let-7a-5p, hsa-miR-novel-chr5_15976, } \\
\text { hsa-miR-28-3p, hsa-miR-151a-5p, and hsa-miR-148a-3p }\end{array}$ & [142] \\
\hline Serum & qRT-PCR & 49,155 & hsa-miR-101, hsa-miR-375, hsa-miR-802 & [144] \\
\hline Serum & qRT-PCR & $100,100,86$ * & hsa-miR-126 & [115] \\
\hline Serum & qRT-PCR & $138,160,157$ * & hsa-miR-126 & [116] \\
\hline Plasma & qRT-PCR & $0,0,40 \$$ & hsa-miR-378, hsa-miR-126-3p, hsa-miR-223-5p & [121] \\
\hline Plasma and plasma exosome & qRT-PCR & $26,26,24 *$ & hsa-miR-15a & [134] \\
\hline
\end{tabular}


Table 8. Cont.

\begin{tabular}{|c|c|c|c|c|}
\hline Sample Type & Profiling Method & Sample Size (Controls, T2D, Other) & Biomarker & Ref. \\
\hline Plasma exosome & qRT-PCR & 18,12 & hsa-miR-326, hsa-let-7a, hsa-let-7f & [155] \\
\hline Platelet & qRT-PCR & $46,43,48 \#, 36^{* *}$ & hsa-miR-103b & [70] \\
\hline Serum & RNA sequencing and qRT-PCR & $3,50,29 * *$ & $\begin{array}{l}\text { hsa-let-7a-5p, hsa-miR-novel-chr5_15976, } \\
\text { hsa-miR-28-3p, hsa-miR-151a-5p, and hsa-miR-148a-3p }\end{array}$ & [142] \\
\hline Serum & qRT-PCR & 49,155 & hsa-miR-101, hsa-miR-375, hsa-miR-802 & [144] \\
\hline Serum & qRT-PCR & $100,100,86^{*}$ & hsa-miR-126 & [115] \\
\hline Serum & qRT-PCR & $40,40,40 \#, 40$ ** & hsa-miR-128 & [156] \\
\hline Serum & qRT-PCR & $0,30,20 * *$ & $\begin{array}{l}\text { hsa-miR-1281, hsa-miR-4687-5p, hsa-miR-4688, } \\
\text { hsa-miR-1260a, and hsa-miR-766-3p }\end{array}$ & [157] \\
\hline Serum & qRT-PCR & $49,49,47 *$ & hsa-miR-130b-3p, hsa-miR-374a-5p & [158] \\
\hline Serum & qRT-PCR & $40,22,34^{* *}$ & hsa-miR-146a & [128] \\
\hline Serum & qRT-PCR & $35,54,16^{*}, 28^{* *}$ & hsa-miR-146a & [130] \\
\hline Serum & qRT-PCR & $138,136,254^{* *}$ & hsa-miR-154-5p & [159] \\
\hline Serum & RNA Sequencing and qRT-PCR & $225,200,470 * *$ & $\begin{array}{l}\text { hsa-miR-16, hsa-miR-23-3p, hsa-miR-122-5p, } \\
\text { hsa-miR-198, hsa-miR-199a-3p, hsa-miR-221, } \\
\text { and hsa-miR-34 }\end{array}$ & [126] \\
\hline Serum & RNA sequencing & $0,11,10^{* *}$ & $\begin{array}{l}\text { hsa-miR-190a-5p, hsa-miR-4448, hsa-miR-338-3p, } \\
\text { hsa-miR-485-5p, and hsa-miR-9-5p }\end{array}$ & [146] \\
\hline Serum & Microarray and qRT-PCR & $25,50,42 * *$ & $\begin{array}{l}\text { hsa-miR-20a, hsa-miR-99b, hsa-miR-122-5p, } \\
\text { and hsa-miR-486-5p }\end{array}$ & [124] \\
\hline Serum & qRT-PCR & $81,30,50 * *$ & $\begin{array}{l}\text { hsa-miR-20b, hsa-miR-17-3p, HOTAIR (lncRNA), and } \\
\text { MALAT1 (lncRNA) }\end{array}$ & [160] \\
\hline Serum & qRT-PCR & 42,45 & hsa-miR-21 & [139] \\
\hline Serum & qRT-PCR & $33,37,64^{* *}$ & hsa-miR-221 & [161] \\
\hline
\end{tabular}


Table 8. Cont.

\begin{tabular}{|c|c|c|c|c|}
\hline Sample Type & Profiling Method & Sample Size (Controls, T2D, Other) & Biomarker & Ref. \\
\hline Serum & Nanostring and qRT-PCR & $0,24,18^{*}$ & hsa-miR-298, hsa-miR-491-5p, hsa-miR-1307-3p & [162] \\
\hline Serum & qRT-PCR & $0,45,45^{* *}$ & hsa-miR-3197 and hsa-miR-2116-5p & [163] \\
\hline Serum & qRT-PCR & $50,50,50 \#, 50$ ** & hsa-miR-342 and hsa-miR-450 & [164] \\
\hline Serum & qRT-PCR & $50,27,23 * *$ & $\begin{array}{l}\text { hsa-miR-421, hsa-miR-212-5p, hsa-miR-3909, } \\
\text { hsa-miR-4677-3p, and hsa-miR-4766-5p }\end{array}$ & [165] \\
\hline Serum & qRT-PCR & $20,13,20 \#, 16^{* *}$ & hsa-miR-503 & [166] \\
\hline Serum & qRT-PCR & $25,25,25 \#, 25$ ** & hsa-miR-593 & [168] \\
\hline Serum & qRT-PCR & $19,18,19$ * & $\begin{array}{l}\text { hsa-miR-9, hsa-miR-29a, hsa-miR-30d, hsa-miR-34a, } \\
\text { hsa-miR-124a, hsa-miR-146a, and hsa-miR-375 }\end{array}$ & [129] \\
\hline Serum & qRT-PCR & 5,10 & $\begin{array}{l}\text { hsa-miR-455-5p, hsa-miR-454-3p, hsa-miR-144-3p, } \\
\text { hsa-miR-96-5p, hsa-miR-665 and hsa-miR-766-3p }\end{array}$ & [169] \\
\hline Serum and serum exosomes & qRT-PCR & $74,76,76^{* *}$ & hsa-miR-7 & [170] \\
\hline Serum exosomes & qRT-PCR & 20,21 & hsa-miR-20b-5p and hsa-miR-150-5p & [133] \\
\hline Serum exosomes & Microarray and qRT-PCR & $0,20,24 * *$ & hsa-miR-377-3p & [67] \\
\hline Whole blood & qRT-PCR & $62,104,108^{* *}$ & hsa-let-7a-2 & [171] \\
\hline Whole blood & qRT-PCR & $30,30,30 *$ & hsa-miR-122, hsa-miR-126-5p, hsa-miR-146a & [120] \\
\hline Whole blood & qRT-PCR & $45,45,45 * *$ & hsa-miR-126 & [117] \\
\hline Whole blood & RNA Sequencing & 3,3 & $\begin{array}{l}\text { hsa-miR-1271-5p, hsa-miR-130a-3p, hsa-miR-130b-3p, } \\
\text { and hsa-miR-574-3p }\end{array}$ & [172] \\
\hline Whole blood & qRT-PCR & $972,94,207 *$ & hsa-miR-1299, hsa-miR-126-3p, hsa-miR-30e-3p & [122] \\
\hline
\end{tabular}


Table 8. Cont.

\begin{tabular}{|c|c|c|c|c|}
\hline Sample Type & Profiling Method & Sample Size (Controls, T2D, Other) & Biomarker & Ref. \\
\hline Whole blood & qRT-PCR & $8,13,8^{*}$ & $\begin{array}{l}\text { hsa-miR-144, hsa-miR-146a, hsa-miR-150, hsa-miR-182, } \\
\text { hsa-miR-192, hsa-miR-30d, hsa-miR-29a, hsa-miR-320 }\end{array}$ & [131] \\
\hline Whole blood & qRT-PCR & $24,24,22 *$ & hsa-miR-15a & [136] \\
\hline Whole blood & qRT-PCR & $30,30,30 *$ & hsa-miR-375, hsa-miR-9 & [145] \\
\hline Whole blood & RNA sequencing and qRT-PCR & $4,4,4^{*}$ & $\begin{array}{l}\text { hsa-miR-98-5p, hsa-miR-143-3p, } \\
\text { hsa-miR-21-3p, hsa-miR-379-5p }\end{array}$ & [140] \\
\hline Whole blood and exosome & qRT-PCR & 46,50 & $\begin{array}{l}\text { hsa-miR-150, hsa-miR-192,hsa-miR-27a, hsa-miR-320a } \\
\text { and hsa-miR-375 }\end{array}$ & [132] \\
\hline
\end{tabular}

* Pre-diabetes; ** T2D patients with complications or comorbidities; \$ T2D patients with treatment; \# non-T2D subjects with comorbidities. 


\subsection{Urine}

\subsubsection{DNA Methylation}

The discovery of biomarkers in DNA methylation using urine samples in diabetes is currently an interesting topic of research. Cell type-specific DNA methylation patterns have been widely studied and used to calculate proportions of particular cell types related to diabetes in blood but not in urine [173]. Studies focusing on biomarkers for the diagnosis of T2D have not been validated in a clinical environment. Instead, the researchers have been more interested in developing biomarkers for one specific comorbidity, kidney disease (Table 9) [173-175]. Because urine examinations identify changes in gene expression in urine-derived cells [176], they may be helpful for the noninvasive assessment of kidney condition and prediction in early T2D [177].

Table 9. DNA methylation biomarkers from urine samples for T2D.

\begin{tabular}{ccccc}
\hline Sample Type & Profiling Method & $\begin{array}{c}\text { Sample Size } \\
\text { (Controls, T2D, Other) }\end{array}$ & Biomarker & Ref. \\
\hline Urine & $\begin{array}{c}\text { Global DNA } \\
\text { Methylation ELISA kit }\end{array}$ & $0,0,308^{* *}$ & $\begin{array}{c}5 \text {-methyl-2'- } \\
\text { deoxycytidine } \\
(5 M e d C)\end{array}$ & [174] \\
\hline Urine & $\begin{array}{c}\text { Illumina Infinium } \\
\text { MethylationEPIC Kit }\end{array}$ & $9,0,4^{* *}$ & SMTNL2 and G6PC & [173] \\
\hline ** T2D patients with complications or comorbidities.
\end{tabular}

\subsection{2. microRNA}

T2D urine miRNA studies mainly studied T2D patients with kidney complications [178-184], except one study compared patients with different T2D treatments [185] (Table 10). Most studies profiled miRNAs from urinary exosomes, while a few profiled urine supernatants $[178,184]$. There is little overlap between the reported miRNAs because some studies selected miRNAs based on their study population. Nevertheless, most miRNAs were upregulated in patients with T2D complications than patients without complications. The results suggest that urine could be an interesting non-invasive source of T2D biomarkers, but more studies are needed to validate these findings.

Table 10. microRNA biomarkers from urine samples for T2D.

\begin{tabular}{|c|c|c|c|c|}
\hline Sample Type & Profiling Method & $\begin{array}{c}\text { Sample Size } \\
\text { (Controls, T2D, Other) }\end{array}$ & Biomarker & Ref. \\
\hline Urine & qRT-PCR & $85,86,92 * *$ & hsa-miR-126 & [184] \\
\hline Urine & qRT-PCR & $0,41,42 * *$ & hsa-miR-29a & [178] \\
\hline Urinary exosome & qRT-PCR & $54,56,110 * *$ & hsa-miR-133b, hsa-miR-342, hsa-miR-30a & [182] \\
\hline Urinary exosome & qRT-PCR & $40,40,80 * *$ & $\begin{array}{l}\text { hsa-miR-15b-5p, hsa-let-7i-5p, } \\
\text { hsa-miR-135b-5p, hsa-miR-24-3p, } \\
\text { hsa-miR-27b-3p, hsa-miR-30a-5p, } \\
\text { hsa-miR-197-3p }\end{array}$ & [179] \\
\hline Urinary exosome & qRT-PCR & $44,46,90 * *$ & hsa-miR-15b, hsa-miR-34a and hsa-miR-636 & [181] \\
\hline Urinary exosome & qRT-PCR & $10,30,50 * *$ & hsa-miR-192, hsa-miR-194, and hsa-miR-215 & [180] \\
\hline Urinary exosome & Nanostring and qPCR & $7,23,34^{* *}$ & hsa-miR-23a-3p & [185] \\
\hline Urinary exosome & Microarray and qRT-PCR & $0,14,14^{* *}$ & $\begin{array}{l}\text { hsa-miR-4687-3p, hsa-miR-4534, } \\
\text { hsa-miR-5007-3p }\end{array}$ & [183] \\
\hline
\end{tabular}

** T2D patients with complications or comorbidities.

\subsection{Other Non-Invasive Biomarkers}

\subsubsection{DNA Methylation}

DNA methylation studies using saliva samples have been more frequent in recent years. Despite this, DNA obtained from saliva is a combination of bacterial and human DNA. Hence, there are unique challenges in using DNA from saliva samples in methylation studies that can affect data quality in epidemiological studies, such as T2D [186]. Currently, there are no empirical studies with evidence for DNA methylation in salivary tissue as 
potential diagnostic biomarkers of T2D. Nonetheless, some studies support the use of DNA methylation from saliva as a prognostic biomarker in comorbidities. In 2011, 39 genes were identified as differentially methylated in two CpG sites in each gene in a group of end-stage renal disease versus diabetes patients without nephropathy. These sites have been involved in kidney development or diabetic nephropathy. As a result, these sites identified in DNA extracted from saliva give proof that they can be used as predictive biomarkers of disease susceptibility [187]. In 2020 a study provided empirical evidence supporting DNA methylation in salivary tissue as a potential predictor of childhood obesity, making NFR1 a target for further exploration as a biomarker [188].

\subsection{2. microRNA}

There is only one salivary miRNA study for T2D biomarkers. The study evaluated four miRNAs that have been reported in T2D and periodontal diseases: hsa-mir-146a, hsa-mir-146b, hsa-mir-155, and hsa-mir-203 [189]. These miRNAs were elevated in T2D patients with healthy periodontium compared to healthy controls, with fold changes from 4.9 to 16.5 , and were able to distinguish groups with high sensitivity and accuracy (0.75-1 and $0.78-0.85$, respectively). The only miRNA that was significantly reduced in T2D patients with periodontitis was hsa-miR-146a, which could predict periodontitis among T2D patients with an accuracy of 0.86 . So, salivary miRNAs are promising T2D biomarkers, and more studies are needed to identify more non-invasive biomarkers.

\section{Conclusions and Future Directions}

Table 11 summarizes and classifies candidate omics biomarkers reported in at least two studies. Most of these biomarkers are risk, diagnostic, prognostic, and response biomarkers profiled from blood samples. To the best of our knowledge, no monitoring DNA or RNA biomarkers have been reported for T2D. So, more longitudinal studies are needed to identify monitoring biomarkers and novel risk biomarkers. Despite many biomarkers reported, there is little overlap between studies due to study methodology differences. For genomic studies, the PRSs can potentially improve biomedical outcomes via precision medicine on T2D. However, large-scale biobanks with diverse ethnic populations need to be considered in more studies to address the need for a broad genomic approach to this global disease.

Biomarker overlap is mainly seen in DNA methylation and miRNA studies (Table 11). Twelve genes were reported in at least two studies for genomics studies and were used as risk biomarkers (Table 11). Only three diagnostic and prognostic biomarkers were reported in at least two mRNA studies (Table 11). The reason is that most mRNA T2D studies are targeted, with researchers focusing on previously reported T2D-related genes. In contrast, most genomics and epigenomics studies used untargeted approaches. Future T2D studies should consider untargeted approaches to identify novel biomarkers.

For circulating miRNA studies, 21 diagnostic miRNAs were reported in at least two studies (Table 11). According to DIANA-miRPath (v3.0) [190] and DIANA-TarBase (v7.0) [191], these miRNAs target 108 genes within the insulin signaling pathway (KEGG pathway hsa04910) (Figure S1, Table S2). Some miRNAs target only one gene, such as hsa-miR-28-3p and SOS2, while other miRNAs target up to 44 genes within the pathway (Table S2). Although not all miRNA-gene interactions in TarBase were reported from diabetes-related tissues, the finding suggests that diagnostic miRNAs play important roles within the insulin signaling pathway (Figure S1).

Lastly, more research on non-invasive biomarkers is needed, especially on T2D patients with no complications. Non-invasive biomarkers would be better for screening and diagnosing T2D in many people. Validation studies are also necessary to confirm the utility of these biomarkers. Nevertheless, these studies have identified potential T2D biomarkers that could help guide future T2D studies. 
Table 11. Classification of potential genomics, transcriptomics, and epigenomics biomarkers of T2D.

\begin{tabular}{|c|c|c|c|c|c|}
\hline Biomarker Type & Definition & Genomics (SNPs) & Transcriptomics (mRNA) & DNA Methylation & miRNA \\
\hline Risk & $\begin{array}{l}\text { Risk for developing T2D in those } \\
\text { who appear healthy }\end{array}$ & $\begin{array}{c}\text { PPARG, FTO, CDC123, TCF7L2, } \\
\text { CDKAL1, WFS1, KCNJ11, } \\
\text { SLC30A8, ADAMTS9, IGF2BP2, } \\
\text { TSPAN8, JAZF1 }\end{array}$ & - & $\begin{array}{c}\text { ABCG1, PHOSPHO1, SOCS3, } \\
\text { SREBF1, TXNIP }\end{array}$ & - \\
\hline Diagnostic & $\begin{array}{l}\text { Confirming the presence of T2D } \\
\text { or identifying a subset of T2D }\end{array}$ & $\begin{array}{l}\text { Ruminococcaceae } \\
\text { (Gut microbiome) }\end{array}$ & $I L-6, I L-8, T T P$ & - & $\begin{array}{c}\text { hsa-miR-126, hsa-miR-126-3p, } \\
\text { hsa-miR-126-5p, hsa-miR-122-5p, } \\
\text { hsa-miR-144, hsa-miR-146a, hsa-miR-150, } \\
\text { hsa-miR-15a, hsa-miR-191, hsa-miR-192, } \\
\text { hsa-miR-20b, hsa-miR-21, hsa-miR-221, } \\
\text { hsa-miR-223, hsa-miR-24, hsa-miR-27a, } \\
\text { hsa-miR-28-3p, hsa-miR-29a, hsa-miR-29b, } \\
\text { hsa-miR-30d, hsa-miR-34a, hsa-miR-375 }\end{array}$ \\
\hline Monitoring & $\begin{array}{l}\text { Measured repeatedly to assess } \\
\text { T2D status }\end{array}$ & - & - & - & - \\
\hline Prognostic & $\begin{array}{l}\text { To identify the likelihood of } \\
\text { progressing from IGT to T2D or } \\
\text { developing T2D complications }\end{array}$ & - & $I L-6, I L-8, T T P$ & - & $\begin{array}{c}\text { hsa-miR-122-5p, hsa-miR-126, } \\
\text { hsa-miR-126-3p, hsa-miR-143-3p, } \\
\text { hsa-miR-144, hsa-miR-146a, hsa-miR-192, } \\
\text { hsa-miR-194, hsa-miR-21, hsa-miR-29a, } \\
\text { hsa-miR-320b, hsa-miR-34a, hsa-miR-375 }\end{array}$ \\
\hline $\begin{array}{l}\text { Pharmacodynamic } \\
\text { /response }\end{array}$ & $\begin{array}{l}\text { To observe T2D treatment } \\
\text { response, not } \\
\text { measured repeatedly }\end{array}$ & - & SOD1 & - & hsa-miR-126, hsa-miR-192 \\
\hline Safety & $\begin{array}{c}\text { To evaluate toxicity response to } \\
\text { a treatment }\end{array}$ & - & - & - & - \\
\hline
\end{tabular}


Supplementary Materials: The following are available online at https: / www.mdpi.com/article /10.3390/ijms23010295/s1.

\begin{abstract}
Author Contributions: Conceptualization, F.P.-M. and G.W.; methodology, F.P.-M. and G.W.; formal analysis, F.P.-M. and G.W.; data curation, F.P.-M. and G.W.; writing-original draft preparation, F.P.-M. and G.W.; writing-review and editing, F.P.-M., G.W., L.S. and A.K.; supervision, L.S. and A.K.; project administration, F.P.-M. and G.W.; funding acquisition, A.K. All authors have read and agreed to the published version of the manuscript.

Funding: This research was conducted within the project which has received funding from the European Union's Horizon 2020 research and innovation program under the Marie SkłodowskaCurie grant agreement No. 754432 and the Polish Ministry of Science and Higher Education, from the financial resources for science in 2018-2023 granted for the implementation of an international co-financed project.
\end{abstract}

Conflicts of Interest: The authors declare no conflict of interest.

\title{
References
}

1. Khan, M.A.B.; Hashim, M.J.; King, J.K.; Govender, R.D.; Mustafa, H.; Al Kaabi, J. Epidemiology of Type 2 Diabetes—Global Burden of Disease and Forecasted Trends. J. Epidemiol. Glob. Health 2020, 10, 107-111. [CrossRef]

2. Herman, W.H.; Ye, W.; Griffin, S.J.; Simmons, R.K.; Davies, M.J.; Khunti, K.; Rutten, G.E.H.M.; Sandbaek, A.; Lauritzen, T.; Borch-Johnsen, K.; et al. Early Detection and Treatment of Type 2 Diabetes Reduce Cardiovascular Morbidity and Mortality: A Simulation of the Results of the Anglo-Danish-Dutch Study of Intensive Treatment in People with Screen-Detected Diabetes in Primary Care (ADDITION-Europe). Diabetes Care 2015, 38, 1449-1455. [CrossRef] [PubMed]

3. American Diabetes Association. 2. Classification and Diagnosis of Diabetes: Standards of Medical Care in Diabetes-2021. Diabetes Care 2021, 44 (Suppl. S1), S15-S33. [CrossRef]

4. Harris, M.I.; Eastman, R.C. Early Detection of Undiagnosed Diabetes Mellitus: A US Perspective. Diabetes Metab. Res. Rev. 2000, 16, 230-236. [CrossRef]

5. Inzucchi, S.E.; Bergenstal, R.M.; Buse, J.B.; Diamant, M.; Ferrannini, E.; Nauck, M.; Peters, A.L.; Tsapas, A.; Wender, R.; Matthews, D.R. Management of Hyperglycemia in Type 2 Diabetes, 2015: A Patient-Centered Approach: Update to a Position Statement of the American Diabetes Association and the European Association for the Study of Diabetes. Diabetes Care 2015, 38, 140-149. [CrossRef] [PubMed]

6. Naylor, S. Biomarkers: Current Perspectives and Future Prospects. Expert Rev. Mol. Diagn. 2003, 3, 525-529. [CrossRef]

7. FDA-NIH Biomarker Working Group. BEST (Biomarkers, EndpointS, and Other Tools) Resource; Food and Drug Administration (US): Silver Spring, MD, USA, 2016.

8. FDA-NIH Biomarker Working Group. Susceptibility/Risk Biomarker; Food and Drug Administration (US): Silver Spring, MD, USA, 2020.

9. FDA-NIH Biomarker Working Group. Diagnostic Biomarker; Food and Drug Administration (US): Silver Spring, MD, USA, 2020.

10. FDA-NIH Biomarker Working Group. Monitoring Biomarker; Food and Drug Administration (US): Silver Spring, MD, USA, 2021.

11. FDA-NIH Biomarker Working Group. Prognostic Biomarker; Food and Drug Administration (US): Silver Spring, MD, USA, 2016.

12. FDA-NIH Biomarker Working Group. Predictive Biomarker; Food and Drug Administration (US): Silver Spring, MD, USA, 2016.

13. FDA-NIH Biomarker Working Group. Pharmacodynamic/Response Biomarker; Food and Drug Administration (US): Silver Spring, MD, USA, 2016.

14. FDA-NIH Biomarker Working Group. Safety Biomarker; Food and Drug Administration (US): Silver Spring, MD, USA, 2016.

15. Laakso, M. Biomarkers for Type 2 Diabetes. Mol. Metab. 2019, 27, S139-S146. [CrossRef]

16. Herder, C.; Karakas, M.; Koenig, W. Biomarkers for the Prediction of Type 2 Diabetes and Cardiovascular Disease. Clin. Pharmacol. Ther. 2011, 90, 52-66. [CrossRef]

17. Abbasi, A.; Sahlqvist, A.-S.; Lotta, L.; Brosnan, J.M.; Vollenweider, P.; Giabbanelli, P.; Nunez, D.J.; Waterworth, D.; Scott, R.A.; Langenberg, C.; et al. A Systematic Review of Biomarkers and Risk of Incident Type 2 Diabetes: An Overview of Epidemiological, Prediction and Aetiological Research Literature. PLoS ONE 2016, 11, e0163721. [CrossRef]

18. Gan, W.Z.; Ramachandran, V.; Lim, C.S.Y.; Koh, R.Y. Omics-Based Biomarkers in the Diagnosis of Diabetes. J. Basic Clin. Physiol. Pharmacol. 2019, 31, 20190120. [CrossRef] [PubMed]

19. Del Giacco, L.; Cattaneo, C. Introduction to Genomics. Methods Mol. Biol. Clifton NJ 2012, 823, 79-88. [CrossRef]

20. Mora, C.; Zonca, V.; Riva, M.A.; Cattaneo, A. Blood Biomarkers and Treatment Response in Major Depression. Expert Rev. Mol. Diagn. 2018, 18, 513-529. [CrossRef]

21. Almgren, P. Heritability and Familiality of Type 2 Diabetes and Related Quantitative Traits in the Botnia Study. Diabetologia 2011, 54, 2811-2819. [CrossRef]

22. Yang, J.; Benyamin, B.; McEvoy, B.P.; Gordon, S.; Henders, A.K.; Nyholt, D.R.; Madden, P.A.; Heath, A.C.; Martin, N.G.; Montgomery, G.W.; et al. Common SNPs Explain a Large Proportion of the Heritability for Human Height. Nat. Genet. 2010, 42, 565-569. [CrossRef] [PubMed]

23. Cooke Bailey, J.N.; Igo, R.P. Genetic Risk Scores. Curr. Protoc. Hum. Genet. 2016, 91, 1-29. [CrossRef] 
24. Wray, N.; Yang, J.; Goddard, M.E.; Visscher, P.M. The Genetic Interpretation of Area under the ROC Curve in Genomic Profiling. PLoS Genet. 2010, 6, e1000864. [CrossRef] [PubMed]

25. Weedon, M.N.; McCarthy, M.I.; Hitman, G.; Walker, M.; Groves, C.J.; Zeggini, E.; Rayner, N.W.; Shields, B.; Owen, K.R.; Hattersley, A.T.; et al. Combining Information from Common Type 2 Diabetes Risk Polymorphisms Improves Disease Prediction. PLoS Med. 2006, 3, e374. [CrossRef]

26. Lango, H.; UK Type 2 Diabetes Genetics Consortium; Palmer, C.N.A.; Morris, A.D.; Zeggini, E.; Hattersley, A.T.; McCarthy, M.I.; Frayling, T.M.; Weedon, M.N. Assessing the Combined Impact of 18 Common Genetic Variants of Modest Effect Sizes on Type 2 Diabetes Risk. Diabetes 2008, 57, 3129-3135. [CrossRef] [PubMed]

27. Meigs, J.B.; Shrader, P.; Sullivan, L.M.; McAteer, J.B.; Fox, C.S.; Dupuis, J.; Manning, A.K.; Florez, J.C.; Wilson, P.W.F.; $\mathrm{D} \backslash$ textquotesingleAgostino, R.B.; et al. Genotype Score in Addition to Common Risk Factors for Prediction of Type 2 Diabetes. N. Engl. J. Med. 2008, 359, 2208-2219. [CrossRef]

28. Lyssenko, V.; Jonsson, A.; Almgren, P.; Pulizzi, N.; Isomaa, B.; Tuomi, T.; Berglund, G.; Altshuler, D.; Nilsson, P.; Groop, L. Clinical Risk Factors, DNA Variants, and the Development of Type 2 Diabetes. N. Engl. J. Med. 2008, 359, 2220-2232. [CrossRef]

29. Morris, A. Large-Scale Association Analysis Provides Insights into the Genetic Architecture and Pathophysiology of Type 2 Diabetes. Nat. Genet. 2012, 44, 981-990. [CrossRef] [PubMed]

30. Vassy, J.L.; Hivert, M.-F.; Porneala, B.; Dauriz, M.; Florez, J.C.; Dupuis, J.; Siscovick, D.S.; Fornage, M.; Rasmussen-Torvik, L.J.; Bouchard, C.; et al. Polygenic Type 2 Diabetes Prediction at the Limit of Common Variant Detection. Diabetes 2014, 63, 2172-2182. [CrossRef] [PubMed]

31. Chikowore, T.; van Zyl, T.; Feskens, E.J.M.; Conradie, K.R. Predictive Utility of a Genetic Risk Score of Common Variants Associated with Type 2 Diabetes in a Black South African Population. Diabetes Res. Clin. Pract. 2016, 122, 1-8. [CrossRef] [PubMed]

32. Lall, K.; Mägi, R.; Morris, A.; Metspalu, A.; Fischer, K. Personalized Risk Prediction for Type 2 Diabetes: The Potential of Genetic Risk Scores. Genet. Med. 2016, 19, 322-329. [CrossRef] [PubMed]

33. Ding, E.L.; Song, Y.; Manson, J.E.; Hunter, D.J.; Lee, C.C.; Rifai, N.; Buring, J.E.; Gaziano, J.M.; Liu, S. Sex Hormone-Binding Globulin and Risk of Type 2 Diabetes in Women and Men. N. Engl. J. Med. 2009, 361, 1152-1163. [CrossRef]

34. Abbasi, A.; Deetman, P.E.; Corpeleijn, E.; Gansevoort, R.T.; Gans, R.O.B.; Hillege, H.L.; van der Harst, P.; Stolk, R.P.; Navis, G.; Alizadeh, B.Z.; et al. Bilirubin as a Potential Causal Factor in Type 2 Diabetes Risk: A Mendelian Randomization Study. Diabetes 2015, 64, 1459-1469. [CrossRef]

35. Wheeler, E.; Leong, A.; Liu, C.-T.; Hivert, M.-F.; Strawbridge, R.J.; Podmore, C.; Li, M.; Yao, J.; Sim, X.; Hong, J.; et al. Impact of Common Genetic Determinants of Hemoglobin A1c on Type 2 Diabetes Risk and Diagnosis in Ancestrally Diverse Populations: A Transethnic Genome-Wide Meta-Analysis. PLoS Med. 2017, 14, e1002383. [CrossRef]

36. El Tarhouny, S.A.; Hadhoud, K.M.; Ebrahem, M.M.; Al Azizi, N.M. Assessment of Cell-Free DNA with Microvascular Complication of Type II Diabetes Mellitus, Using PCR and Elisa. Nucleosides Nucleotides Nucleic Acids 2010, 29, 228-236. [CrossRef]

37. Silzer, T.; Barber, R.; Sun, J.; Pathak, G.; Johnson, L.; O’Bryant, S.; Phillips, N. Circulating Mitochondrial DNA: New Indices of Type 2 Diabetes-Related Cognitive Impairment in Mexican Americans. PLoS ONE 2019, 14, e213527. [CrossRef]

38. Bosschieter, J.; Bach, S.; Bijnsdorp, I.V.; Segerink, L.I.; Rurup, W.F.; van Splunter, A.P.; Bahce, I.; Novianti, P.W.; Kazemier, G.; van Moorselaar, R.J.A.; et al. A Protocol for Urine Collection and Storage Prior to DNA Methylation Analysis. PLoS ONE 2018, 13, e0200906. [CrossRef]

39. Hilhorst, M.; Theunissen, R.; van Rie, H.; van Paassen, P.; Tervaert, J.W.C. DNA Extraction from Long-Term Stored Urine. BMC Nephrol. 2013, 14, 238. [CrossRef] [PubMed]

40. Cao, H.; Wu, J.; Luo, J.; Chen, X.; Yang, J.; Fang, L. Urinary Mitochondrial DNA: A Potential Early Biomarker of Diabetic Nephropathy. Diabetes Metab. Res. Rev. 2019, 35, e3131. [CrossRef] [PubMed]

41. Franceschini, N.; Shara, N.M.; Wang, H.; Voruganti, V.S.; Laston, S.; Haack, K.; Lee, E.T.; Best, L.G.; Maccluer, J.W.; Cochran, B.J.; et al. The Association of Genetic Variants of Type 2 Diabetes with Kidney Function. Kidney Int. 2012, 82, 220-225. [CrossRef]

42. Prior, S.L.; Clark, A.R.; Jones, D.A.; Bain, S.C.; Hurel, S.J.; Humphries, S.E.; Stephens, J.W. Association of the PGC-1 $\alpha$ Rs8192678 Variant with Microalbuminuria in Subjects with Type 2 Diabetes Mellitus. Dis. Markers 2012, 32, 363-369. [CrossRef] [PubMed]

43. Reutens, A.T.; Atkins, R.C. Epidemiology of Diabetic Nephropathy. Contrib. Nephrol. 2011, 170, 1-7. [CrossRef]

44. Bruinsma, F.J.; Joo, J.E.; Wong, E.M.; Giles, G.G.; Southey, M.C. The Utility of DNA Extracted from Saliva for Genome-Wide Molecular Research Platforms. BMC Res. Notes 2018, 11, 8. [CrossRef]

45. Kogawa, E.M.; Grisi, D.C.; Falcão, D.P.; Amorim, I.A.; Rezende, T.M.B.; da Silva, I.C.R.; Silva, O.N.; Franco, O.L.; de Amorim, R.F.B. Salivary Function Impairment in Type 2 Diabetes Patients Associated with Concentration and Genetic Polymorphisms of Chromogranin A. Clin. Oral Investig. 2016, 20, 2083-2095. [CrossRef]

46. Thomas, T.; Gilbert, J.; Meyer, F. Metagenomics-A Guide from Sampling to Data Analysis. Microb. Inform. Exp. 2012, 2, 3. [CrossRef]

47. Sun, X.; Li, M.; Xia, L.; Fang, Z.; Yu, S.; Gao, J.; Feng, Q.; Yang, P. Alteration of Salivary Microbiome in Periodontitis with or without Type-2 Diabetes Mellitus and Metformin Treatment. Sci. Rep. 2020, 10, 15363. [CrossRef]

48. Wang, Y.; Luo, X.; Mao, X.; Tao, Y.; Ran, X.; Zhao, H.; Xiong, J.; Li, L. Gut Microbiome Analysis of Type 2 Diabetic Patients from the Chinese Minority Ethnic Groups the Uygurs and Kazaks. PLoS ONE 2017, 12, e0172774. [CrossRef] [PubMed] 
49. Yassour, M.; Lim, M.Y.; Yun, H.S.; Tickle, T.L.; Sung, J.; Song, Y.-M.; Lee, K.; Franzosa, E.A.; Morgan, X.C.; Gevers, D.; et al. Sub-Clinical Detection of Gut Microbial Biomarkers of Obesity and Type 2 Diabetes. Genome Med. 2016, 8, 17. [CrossRef]

50. Qiu, Q.; Wang, J.; Yan, Y.; Roy, B.; Chen, Y.; Shang, X.; Dou, T.; Han, L. Metagenomic Analysis Reveals the Distribution of Antibiotic Resistance Genes in a Large-Scale Population of Healthy Individuals and Patients with Varied Diseases. Front. Mol. Biosci. 2020, 7, 590018. [CrossRef]

51. Diener, C.; Reyes-Escogido, M.D.; Jimenez-Ceja, L.M.; Matus, M.; Gomez-Navarro, C.M.; Chu, N.D.; Zhong, V.; Tejero, M.E.; Alm, E.; Resendis-Antonio, O.; et al. Progressive Shifts in the Gut Microbiome Reflect Prediabetes and Diabetes Development in a Treatment-Naive Mexican Cohort. Front. Endocrinol. 2021, 11, 602326. [CrossRef] [PubMed]

52. Tian, R.; Liu, H.; Feng, S.; Wang, H.; Wang, Y.; Wang, Y.; Liang, L.; Xu, H.; Xing, H.; Zhang, S. Gut Microbiota Dysbiosis in Stable Coronary Artery Disease Combined with Type 2 Diabetes Mellitus Influences Cardiovascular Prognosis. Nutr. Metab. Cardiovasc. Dis. 2021, 31, 1454-1466. [CrossRef]

53. Whitney, D.; Skoletsky, J.; Moore, K.; Boynton, K.; Kann, L.; Brand, R.; Syngal, S.; Lawson, M.; Shuber, A. Enhanced Retrieval of DNA from Human Fecal Samples Results in Improved Performance of Colorectal Cancer Screening Test. J. Mol. Diagn. JMD 2004, 6, 386-395. [CrossRef]

54. Karlsson, F.H.; Tremaroli, V.; Nookaew, I.; Bergström, G.; Behre, C.J.; Fagerberg, B.; Nielsen, J.; Bäckhed, F. Gut Metagenome in European Women with Normal, Impaired and Diabetic Glucose Control. Nature 2013, 498, 99-103. [CrossRef]

55. Barengolts, E.; Green, S.J.; Eisenberg, Y.; Akbar, A.; Reddivari, B.; Layden, B.T.; Dugas, L.; Chlipala, G. Gut Microbiota Varies by Opioid Use, Circulating Leptin and Oxytocin in African American Men with Diabetes and High Burden of Chronic Disease. PLoS ONE 2018, 13, e0194171. [CrossRef] [PubMed]

56. Yamaguchi, Y.; Adachi, K.; Sugiyama, T.; Shimozato, A.; Ebi, M.; Ogasawara, N.; Funaki, Y.; Goto, C.; Sasaki, M.; Kasugai, K. Association of Intestinal Microbiota with Metabolic Markers and Dietary Habits in Patients with Type 2 Diabetes. Digestion 2016, 94, 66-72. [CrossRef]

57. Qin, J.; Li, Y.; Cai, Z.; Li, S.; Zhu, J.; Zhang, F.; Liang, S.; Zhang, W.; Guan, Y.; Shen, D.; et al. A Metagenome-Wide Association Study of Gut Microbiota in Type 2 Diabetes. Nature 2012, 490, 55-60. [CrossRef]

58. Mutz, K.-O.; Heilkenbrinker, A.; Lönne, M.; Walter, J.-G.; Stahl, F. Transcriptome Analysis Using Next-Generation Sequencing. Curr. Opin. Biotechnol. 2013, 24, 22-30. [CrossRef]

59. Olivier, M.; Asmis, R.; Hawkins, G.A.; Howard, T.D.; Cox, L.A. The Need for Multi-Omics Biomarker Signatures in Precision Medicine. Int. J. Mol. Sci. 2019, 20, 4781. [CrossRef]

60. Liu, F.; Guo, J.; Zhang, Q.; Liu, D.; Wen, L.; Yang, Y.; Yang, L.; Liu, Z. The Expression of Tristetraprolin and Its Relationship with Urinary Proteins in Patients with Diabetic Nephropathy. PLoS ONE 2015, 10, e0141471. [CrossRef]

61. Soundararajan, A.; Prabu, P.; Mohan, V.; Gibert, Y.; Balasubramanyam, M. Novel Insights of Elevated Systemic Levels of Bisphenol-A (BPA) Linked to Poor Glycemic Control, Accelerated Cellular Senescence and Insulin Resistance in Patients with Type 2 Diabetes. Mol. Cell. Biochem. 2019, 458, 171-183. [CrossRef] [PubMed]

62. Dehghani, M.; Aghaei Zarch, S.M.; Vahidi Mehrjardi, M.Y.; Nazari, M.; Babakhanzadeh, E.; Ghadimi, H.; Zeinali, F.; Talebi, M. Evaluation of MiR-181b and MiR-126-5p Expression Levels in T2DM Patients Compared to Healthy Individuals: Relationship with NF-KB Gene Expression. Endocrinol. Diabetes Nutr. Engl. Ed. 2020, 67, 454-460. [CrossRef]

63. Fatima, N.; Faisal, S.M.; Zubair, S.; Siddiqui, S.S.; Moin, S.; Owais, M. Emerging Role of Interleukins IL-23/IL-17 Axis and Biochemical Markers in the Pathogenesis of Type 2 Diabetes: Association with Age and Gender in Human Subjects. Int. J. Biol. Macromol. 2017, 105, 1279-1288. [CrossRef] [PubMed]

64. Balasubramanyam, M.; Aravind, S.; Gokulakrishnan, K.; Prabu, P.; Sathishkumar, C.; Ranjani, H.; Mohan, V. Impaired MiR146a Expression Links Subclinical Inflammation and Insulin Resistance in Type 2 Diabetes. Mol. Cell. Biochem. 2011, 351, 197-205. [CrossRef] [PubMed]

65. Al-Harithy, R.N.; Alomari, A.S. Expression of Leptin MRNA as Non-invasive Biomarker in Type 2 Diabetes Mellitus. Int. J. Clin. Pract. 2021, e14844. [CrossRef]

66. Tao, Y.; Wei, X.; Yue, Y.; Wang, J.; Li, J.; Shen, L.; Lu, G.; He, Y.; Zhao, S.; Zhao, F.; et al. Extracellular Vesicle-Derived AEBP1 MRNA as a Novel Candidate Biomarker for Diabetic Kidney Disease. J. Transl. Med. 2021, 19, 326. [CrossRef]

67. Jiang, L.; Cao, H.; Deng, T.; Yang, M.; Meng, T.; Yang, H.; Luo, X. Serum Exosomal MiR-377-3p Inhibits Retinal Pigment Epithelium Proliferation and Offers a Biomarker for Diabetic Macular Edema. J. Int. Med. Res. 2021, 49, 03000605211002975. [CrossRef]

68. Que, Y.; Shen, X. Changes in Blood Monocyte Toll-like Receptor and Serum Surfactant Protein A Reveal a Pathophysiological Mechanism for Community-Acquired Pneumonia in Patients with Type 2 Diabetes: Changes of TLR and SP-A in Diabetes and Pneumonia. Intern. Med. J. 2016, 46, 213-219. [CrossRef]

69. Rashad, N.M.; Ahmed, H.S.; Ashour, W.M.R.; Yousef, M.S. Association of Vaspin Gene Expression and Its Serum Level on the Risk of Ischemic Stroke in Type 2 Diabetic Egyptian Patients: Prospective Case-Control Study. Biotechnol. Appl. Biochem. 2020, 67, 912-919. [CrossRef] [PubMed]

70. Luo, M.; Li, R.; Deng, X.; Ren, M.; Chen, N.; Zeng, M.; Yan, K.; Xia, J.; Liu, F.; Ma, W.; et al. Platelet-Derived MiR-103b as a Novel Biomarker for the Early Diagnosis of Type 2 Diabetes. Acta Diabetol. 2015, 52, 943-949. [CrossRef] [PubMed] 
71. Fan, S.; Wang, Z.; Li, Q.; Luo, L.; Zhu, Y.; Yang, Y. The Relationship between BSP MRNA Expression and 25(OH)D/OPG in Peripheral Blood of Newly Diagnosed T2DM Patients with Different Bone Mass. Endokrynol. Pol. 2020, 71, 160-167. [CrossRef] [PubMed]

72. Nazem, M.R.; Asadi, M.; Jabbari, N.; Allameh, A. Effects of Zinc Supplementation on Superoxide Dismutase Activity and Gene Expression, and Metabolic Parameters in Overweight Type 2 Diabetes Patients: A Randomized, Double-Blind, Controlled Trial. Clin. Biochem. 2019, 69, 15-20. [CrossRef]

73. Fayed, A.; Rahman Tohamy, I.A.; Kahla, H.; Elsayed, N.M.; El Ansary, M.; Saadi, G. Urinary Podocyte-Associated MRNA Profile in Egyptian Patients with Diabetic Nephropathy. Diabetes Metab. Syndr. Clin. Res. Rev. 2019, 13, 2849-2854. [CrossRef]

74. Yamamoto, C.M.; Murakami, T.; Oakes, M.L.; Mitsuhashi, M.; Kelly, C.; Henry, R.R.; Sharma, K. Uromodulin MRNA from Urinary Extracellular Vesicles Correlate to Kidney Function Decline in Type 2 Diabetes Mellitus. Am. J. Nephrol. 2018, 47, 283-291. [CrossRef]

75. Lee, Y.-H.; Joshipura, K.; Vergara, J.L.; Wong, D.T. Detection of Type II Diabetes Mellitus Using Salivary Transcriptomic Biomarkers. Genomic Med. Biomark. Health Sci. 2012, 4, 7-11. [CrossRef]

76. Wang, K.C.; Chang, H.Y. Epigenomics-Technologies and Applications. Circ. Res. 2018, 122, 1191-1199. [CrossRef]

77. Moore, L.D.; Le, T.; Fan, G. DNA Methylation and Its Basic Function. Neuropsychopharmacology 2013, 38, 23-38. [CrossRef]

78. Kim, V.N.; Han, J.; Siomi, M.C. Biogenesis of Small RNAs in Animals. Nat. Rev. Mol. Cell Biol. 2009, 10, 126-139. [CrossRef]

79. Bartel, D.P. MicroRNAs: Target Recognition and Regulatory Functions. Cell 2009, 136, 215-233. [CrossRef] [PubMed]

80. Chambers, J.C.; Loh, M.; Lehne, B.; Drong, A.; Kriebel, J.; Motta, V.; Wahl, S.; Elliott, H.R.; Rota, F.; Scott, W.R.; et al. EpigenomeWide Association of DNA Methylation Markers in Peripheral Blood from Indian Asians and Europeans with Incident Type 2 Diabetes: A Nested Case-Control Study. Lancet Diabetes Endocrinol. 2015, 3, 526-534. [CrossRef]

81. Kulkarni, H.; Kos, M.Z.; Neary, J.; Dyer, T.D.; Kent, J.W.; Göring, H.H.H.; Cole, S.A.; Comuzzie, A.G.; Almasy, L.; Mahaney, M.C.; et al. Novel Epigenetic Determinants of Type 2 Diabetes in Mexican-American Families. Hum. Mol. Genet. 2015, 24, 5330-5344. [CrossRef] [PubMed]

82. Al Muftah, W.A.; Al-Shafai, M.; Zaghlool, S.B.; Visconti, A.; Tsai, P.-C.; Kumar, P.; Spector, T.; Bell, J.; Falchi, M.; Suhre, K. Epigenetic Associations of Type 2 Diabetes and BMI in an Arab Population. Clin. Epigenetics 2016, 8, 13. [CrossRef]

83. Dayeh, T.; Tuomi, T.; Almgren, P.; Perfilyev, A.; Jansson, P.-A.; de Mello, V.D.; Pihlajamäki, J.; Vaag, A.; Groop, L.; Nilsson, E.; et al. DNA Methylation of Loci within ABCG1 and PHOSPHO1 in Blood DNA Is Associated with Future Type 2 Diabetes Risk. Epigenetics 2016, 11, 482-488. [CrossRef]

84. Walaszczyk, E.; Luijten, M.; Spijkerman, A.M.W.; Bonder, M.J.; Lutgers, H.L.; Snieder, H.; Wolffenbuttel, B.H.R.; van VlietOstaptchouk, J.V. DNA Methylation Markers Associated with Type 2 Diabetes, Fasting Glucose and HbA1c Levels: A Systematic Review and Replication in a Case-Control Sample of the Lifelines Study. Diabetologia 2018, 61, 354-368. [CrossRef]

85. Krause, C.; Sievert, H.; Geißler, C.; Grohs, M.; El Gammal, A.T.; Wolter, S.; Ohlei, O.; Kilpert, F.; Krämer, U.M.; Kasten, M.; et al. Critical Evaluation of the DNA-Methylation Markers ABCG1 and SREBF1 for Type 2 Diabetes Stratification. Epigenomics 2019, 11, 885-897. [CrossRef] [PubMed]

86. Meeks, K.A.C.; Henneman, P.; Venema, A.; Addo, J.; Bahendeka, S.; Burr, T.; Danquah, I.; Galbete, C.; Mannens, M.M.A.M.; Mockenhaupt, F.P.; et al. Epigenome-Wide Association Study in Whole Blood on Type 2 Diabetes among Sub-Saharan African Individuals: Findings from the RODAM Study. Int. J. Epidemiol. 2019, 48, 58-70. [CrossRef]

87. Tarling, E.J. Expanding Roles of ABCG1 and Sterol Transport. Curr. Opin. Lipidol. 2013, 24, 138-146. [CrossRef]

88. Hidalgo, B.; Irvin, M.R.; Sha, J.; Zhi, D.; Aslibekyan, S.; Absher, D.; Tiwari, H.K.; Kabagambe, E.K.; Ordovas, J.M.; Arnett, D.K. Epigenome-Wide Association Study of Fasting Measures of Glucose, Insulin, and HOMA-IR in the Genetics of Lipid Lowering Drugs and Diet Network Study. Diabetes 2014, 63, 801-807. [CrossRef]

89. Cha-Molstad, H.; Saxena, G.; Chen, J.; Shalev, A. Glucose-Stimulated Expression of Txnip Is Mediated by Carbohydrate Response Element-Binding Protein, P300, and Histone H4 Acetylation in Pancreatic Beta Cells. J. Biol. Chem. 2009, 284, 16898-16905. [CrossRef]

90. Minn, A.H.; Hafele, C.; Shalev, A. Thioredoxin-Interacting Protein Is Stimulated by Glucose through a Carbohydrate Response Element and Induces Beta-Cell Apoptosis. Endocrinology 2005, 146, 2397-2405. [CrossRef]

91. Vitto, M.F.; Luz, G.; Luciano, T.F.; Marques, S.O.; Souza, D.R.; Pinho, R.A.; Lira, F.S.; Cintra, D.E.; De Souza, C.T. Reversion of Steatosis by SREBP-1c Antisense Oligonucleotide Did Not Improve Hepatic Insulin Action in Diet-Induced Obesity Mice. Horm. Metab. Res. Horm. Stoffwechselforschung Horm. Metab. 2012, 44, 885-890. [CrossRef]

92. Bobryshev, Y.V.; Orekhov, A.N.; Sobenin, I.; Chistiakov, D.A. Role of Bone-Type Tissue-Nonspecific Alkaline Phosphatase and PHOSPO1 in Vascular Calcification. Curr. Pharm. Des. 2014, 20, 5821-5828. [CrossRef] [PubMed]

93. Gemma, C.; Sookoian, S.; Dieuzeide, G.; García, S.I.; Gianotti, T.F.; González, C.D.; Pirola, C.J. Methylation of TFAM Gene Promoter in Peripheral White Blood Cells Is Associated with Insulin Resistance in Adolescents. Mol. Genet. Metab. 2010, 100, 83-87. [CrossRef]

94. Toperoff, G.; Aran, D.; Kark, J.D.; Rosenberg, M.; Dubnikov, T.; Nissan, B.; Wainstein, J.; Friedlander, Y.; Levy-Lahad, E.; Glaser, B.; et al. Genome-Wide Survey Reveals Predisposing Diabetes Type 2-Related DNA Methylation Variations in Human Peripheral Blood. Hum. Mol. Genet. 2012, 21, 371-383. [CrossRef] 
95. Gu, H.F.; Gu, T.; Hilding, A.; Zhu, Y.; Kärvestedt, L.; Östenson, C.-G.; Lai, M.; Kutsukake, M.; Frystyk, J.; Tamura, K.; et al. Evaluation of IGFBP-7 DNA Methylation Changes and Serum Protein Variation in Swedish Subjects with and without Type 2 Diabetes. Clin. Epigenetics 2013, 5, 20. [CrossRef]

96. Zou, L.; Yan, S.; Guan, X.; Pan, Y.; Qu, X. Hypermethylation of the PRKCZ Gene in Type 2 Diabetes Mellitus. J. Diabetes Res. 2013, 2013, 721493. [CrossRef]

97. Canivell, S.; Ruano, E.G.; Sisó-Almirall, A.; Kostov, B.; Paz, L.G.; Fernandez-Rebollo, E.; Hanzu, F.A.; Párrizas, M.; Novials, A.; Gomis, R. Differential Methylation of TCF7L2 Promoter in Peripheral Blood DNA in Newly Diagnosed, Drug-Naïve Patients with Type 2 Diabetes. PLoS ONE 2014, 9, e99310. [CrossRef] [PubMed]

98. Martín-Núñez, G.M.; Rubio-Martín, E.; Cabrera-Mulero, R.; Rojo-Martínez, G.; Olveira, G.; Valdés, S.; Soriguer, F.; Castaño, L.; Morcillo, S. Type 2 Diabetes Mellitus in Relation to Global LINE-1 DNA Methylation in Peripheral Blood: A Cohort Study. Epigenetics 2014, 9, 1322-1328. [CrossRef] [PubMed]

99. Seman, N.A.; Mohamud, W.N.W.; Östenson, C.-G.; Brismar, K.; Gu, H.F. Increased DNA Methylation of the SLC30A8 Gene Promoter Is Associated with Type 2 Diabetes in a Malay Population. Clin. Epigenetics 2015, 7, 30. [CrossRef] [PubMed]

100. Florath, I.; Butterbach, K.; Heiss, J.; Bewerunge-Hudler, M.; Zhang, Y.; Schöttker, B.; Brenner, H. Type 2 Diabetes and Leucocyte DNA Methylation: An Epigenome-Wide Association Study in over 1500 Older Adults. Diabetologia 2016, 59, 130-138. [CrossRef] [PubMed]

101. Soriano-Tárraga, C.; Jiménez-Conde, J.; Giralt-Steinhauer, E.; Mola-Caminal, M.; Vivanco-Hidalgo, R.M.; Ois, A.; RodríguezCampello, A.; Cuadrado-Godia, E.; Sayols-Baixeras, S.; Elosua, R.; et al. Epigenome-Wide Association Study Identifies TXNIP Gene Associated with Type 2 Diabetes Mellitus and Sustained Hyperglycemia. Hum. Mol. Genet. 2016, 25, 609-619. [CrossRef]

102. Jeon, J.-P.; Koh, I.-U.; Choi, N.-H.; Kim, B.-J.; Han, B.-G.; Lee, S. Differential DNA Methylation of MSI2 and Its Correlation with Diabetic Traits. PLoS ONE 2017, 12, e0177406. [CrossRef] [PubMed]

103. van Otterdijk, S.D.; Binder, A.M.; Szarc Vel Szic, K.; Schwald, J.; Michels, K.B. DNA Methylation of Candidate Genes in Peripheral Blood from Patients with Type 2 Diabetes or the Metabolic Syndrome. PLoS ONE 2017, 12, e0180955. [CrossRef]

104. Nilsson, E.; Jansson, P.A.; Perfilyev, A.; Volkov, P.; Pedersen, M.; Svensson, M.K.; Poulsen, P.; Ribel-Madsen, R.; Pedersen, N.L.; Almgren, P.; et al. Altered DNA Methylation and Differential Expression of Genes Influencing Metabolism and Inflammation in Adipose Tissue from Subjects with Type 2 Diabetes. Diabetes 2014, 63, 2962-2976. [CrossRef]

105. Illig, T.; Gieger, C.; Zhai, G.; Römisch-Margl, W.; Wang-Sattler, R.; Prehn, C.; Altmaier, E.; Kastenmüller, G.; Kato, B.S.; Mewes, H.-W.; et al. A Genome-Wide Perspective of Genetic Variation in Human Metabolism. Nat. Genet. 2010, 42, 137-141. [CrossRef]

106. Hwang, J.-Y.; Lee, H.J.; Go, M.J.; Jang, H.B.; Choi, N.-H.; Bae, J.B.; Castillo-Fernandez, J.E.; Bell, J.T.; Spector, T.D.; Lee, H.-J.; et al. Genome-Wide Methylation Analysis Identifies ELOVL5 as an Epigenetic Biomarker for the Risk of Type 2 Diabetes Mellitus. Sci. Rep. 2018, 8, 14862. [CrossRef]

107. Zampetaki, A.; Kiechl, S.; Drozdov, I.; Willeit, P.; Mayr, U.; Prokopi, M.; Mayr, A.; Weger, S.; Oberhollenzer, F.; Bonora, E.; et al. Plasma MicroRNA Profiling Reveals Loss of Endothelial MiR-126 and Other MicroRNAs in Type 2 Diabetes. Circ. Res. 2010, 107, 810-817. [CrossRef]

108. Meng, S.; Cao, J.-T.; Zhang, B.; Zhou, Q.; Shen, C.-X.; Wang, C.-Q. Downregulation of MicroRNA-126 in Endothelial Progenitor Cells from Diabetes Patients, Impairs Their Functional Properties, via Target Gene Spred-1. J. Mol. Cell. Cardiol. 2012, 53, 64-72. [CrossRef]

109. Zhang, T.; Lv, C.; Li, L.; Chen, S.; Liu, S.; Wang, C.; Su, B. Plasma MiR-126 Is a Potential Biomarker for Early Prediction of Type 2 Diabetes Mellitus in Susceptible Individuals. BioMed Res. Int. 2013, 2013, e761617. [CrossRef]

110. Ortega, F.J.; Mercader, J.M.; Moreno-Navarrete, J.M.; Rovira, O.; Guerra, E.; Esteve, E.; Xifra, G.; Martínez, C.; Ricart, W.; Rieusset, J.; et al. Profiling of Circulating MicroRNAs Reveals Common MicroRNAs Linked to Type 2 Diabetes That Change with Insulin Sensitization. Diabetes Care 2014, 37, 1375-1383. [CrossRef]

111. Amr, K.; Abdelmawgoud, H.; Ali, Z.; Shehata, S.; Raslan, H. Potential Value of Circulating MicroRNA-126 and MicroRNA-210 as Biomarkers for Type 2 Diabetes with Coronary Artery Disease. Br. J. Biomed. Sci. 2018, 75, 82-87. [CrossRef]

112. Jiménez-Lucena, R.; Rangel-Zúñiga, O.A.; Alcalá-Díaz, J.F.; López-Moreno, J.; Roncero-Ramos, I.; Molina-Abril, H.; YuberoSerrano, E.M.; Caballero-Villarraso, J.; Delgado-Lista, J.; Castaño, J.P.; et al. Circulating MiRNAs as Predictive Biomarkers of Type 2 Diabetes Mellitus Development in Coronary Heart Disease Patients from the CORDIOPREV Study. Mol. Ther.-Nucleic Acids 2018, 12, 146-157. [CrossRef]

113. Zhang, T.; Li, L.; Shang, Q.; Lv, C.; Wang, C.; Su, B. Circulating MiR-126 Is a Potential Biomarker to Predict the Onset of Type 2 Diabetes Mellitus in Susceptible Individuals. Biochem. Biophys. Res. Commun. 2015, 463, 60-63. [CrossRef] [PubMed]

114. Jansen, F.; Wang, H.; Przybilla, D.; Franklin, B.S.; Dolf, A.; Pfeifer, P.; Schmitz, T.; Flender, A.; Endl, E.; Nickenig, G.; et al. Vascular Endothelial Microparticles-Incorporated MicroRNAs Are Altered in Patients with Diabetes Mellitus. Cardiovasc. Diabetol. 2016, 15, 49. [CrossRef] [PubMed]

115. Rezk, N.A.; Sabbah, N.A.; Saad, M.S.S. Role of MicroRNA 126 in Screening, Diagnosis, and Prognosis of Diabetic Patients in Egypt. IUBMB Life 2016, 68, 452-458. [CrossRef]

116. Liu, Y.; Gao, G.; Yang, C.; Zhou, K.; Shen, B.; Liang, H.; Jiang, X. The Role of Circulating MicroRNA-126 (MiR-126): A Novel Biomarker for Screening Prediabetes and Newly Diagnosed Type 2 Diabetes Mellitus. Int. J. Mol. Sci. 2014, 15, 10567-10577. [CrossRef] [PubMed] 
117. Al-Kafaji, G.; Al-Mahroos, G.; Abdulla Al-Muhtaresh, H.; Sabry, M.A.; Abdul Razzak, R.; Salem, A.H. Circulating EndotheliumEnriched MicroRNA-126 as a Potential Biomarker for Coronary Artery Disease in Type 2 Diabetes Mellitus Patients. Biomarkers 2017, 22, 268-278. [CrossRef]

118. Olivieri, F.; Bonafè, M.; Spazzafumo, L.; Gobbi, M.; Prattichizzo, F.; Recchioni, R.; Marcheselli, F.; La Sala, L.; Galeazzi, R.; Rippo, M.R.; et al. Age- and Glycemia-Related MiR-126-3p Levels in Plasma and Endothelial Cells. Aging 2014, 6, 771-787. [CrossRef]

119. Olivieri, F.; Spazzafumo, L.; Bonafè, M.; Recchioni, R.; Prattichizzo, F.; Marcheselli, F.; Micolucci, L.; Mensà, E.; Giuliani, A.; Santini, G.; et al. MiR-21-5p and MiR-126a-3p Levels in Plasma and Circulating Angiogenic Cells: Relationship with Type 2 Diabetes Complications. Oncotarget 2015, 6, 35372-35382. [CrossRef]

120. Zeinali, F.; Zarch, S.M.A.; Jahan-Mihan, A.; Kalantar, S.M.; Mehrjardi, M.Y.V.; Fallahzadeh, H.; Hosseinzadeh, M.; Rahmanian, M.; Mozaffari-Khosravi, H. Circulating MicroRNA-122, MicroRNA-126-3p and MicroRNA-146a Are Associated with Inflammation in Patients with Pre-Diabetes and Type 2 Diabetes Mellitus: A Case Control Study. PLoS ONE 2021, 16, e0251697. [CrossRef]

121. Catanzaro, G.; Besharat, Z.M.; Chiacchiarini, M.; Abballe, L.; Sabato, C.; Vacca, A.; Borgiani, P.; Dotta, F.; Tesauro, M.; Po, A.; et al. Circulating MicroRNAs in Elderly Type 2 Diabetic Patients. Int. J. Endocrinol. 2018, 2018, 6872635. [CrossRef]

122. Weale, C.J.; Matshazi, D.M.; Davids, S.F.G.; Raghubeer, S.; Erasmus, R.T.; Kengne, A.P.; Davison, G.M.; Matsha, T.E. MicroRNAs1299, -126-3p and -30e-3p as Potential Diagnostic Biomarkers for Prediabetes. Diagnostics 2021, 11, 949. [CrossRef] [PubMed]

123. de Boer, H.C.; van Solingen, C.; Prins, J.; Duijs, J.M.G.J.; Huisman, M.V.; Rabelink, T.J.; van Zonneveld, A.J. Aspirin Treatment Hampers the Use of Plasma MicroRNA-126 as a Biomarker for the Progression of Vascular Disease. Eur. Heart J. 2013, 34, 3451-3457. [CrossRef] [PubMed]

124. Regmi, A.; Liu, G.; Zhong, X.; Hu, S.; Ma, R.; Gou, L.; Zafar, M.I.; Chen, L. Evaluation of Serum MicroRNAs in Patients with Diabetic Kidney Disease: A Nested Case-Controlled Study and Bioinformatics Analysis. Med. Sci. Monit. 2019, 25, 1699-1708. [CrossRef]

125. Ghai, V.; Baxter, D.; Wu, X.; Kim, T.-K.; Kuusisto, J.; Laakso, M.; Connolly, T.; Li, Y.; Andrade-Gordon, P.; Wang, K. Circulating RNAs as Predictive Markers for the Progression of Type 2 Diabetes. J. Cell. Mol. Med. 2019, 23, 2753-2768. [CrossRef]

126. Elemeery, M.N.; Mohamed, M.A.; Madkour, M.A.; Shamseya, M.M.; Issa, N.M.; Badr, A.N.; Ghareeb, D.A.; Pan, C.-H. MicroRNA Signature in Patients with Hepatocellular Carcinoma Associated with Type 2 Diabetes. World J. Gastroenterol. 2019, 25 6322-6341. [CrossRef] [PubMed]

127. Rong, Y.; Bao, W.; Shan, Z.; Liu, J.; Yu, X.; Xia, S.; Gao, H.; Wang, X.; Yao, P.; Hu, F.B.; et al. Increased MicroRNA-146a Levels in Plasma of Patients with Newly Diagnosed Type 2 Diabetes Mellitus. PLoS ONE 2013, 8, e73272. [CrossRef] [PubMed]

128. Baldeón, L.; Weigelt, K.; de Wit, H.; Ozcan, B.; van Oudenaren, A.; Sempértegui, F.; Sijbrands, E.; Grosse, L.; Freire, W.; Drexhage, H.A.; et al. Decreased Serum Level of MiR-146a as Sign of Chronic Inflammation in Type 2 Diabetic Patients. PLoS ONE 2014, 9, e115209. [CrossRef]

129. Kong, L.; Zhu, J.; Han, W.; Jiang, X.; Xu, M.; Zhao, Y.; Dong, Q.; Pang, Z.; Guan, Q.; Gao, L.; et al. Significance of Serum MicroRNAs in Pre-Diabetes and Newly Diagnosed Type 2 Diabetes: A Clinical Study. Acta Diabetol. 2011, 48, 61-69. [CrossRef] [PubMed]

130. García-Jacobo, R.E.; Uresti-Rivera, E.E.; Portales-Pérez, D.P.; González-Amaro, R.; Lara-Ramírez, E.E.; Enciso-Moreno, J.A.; GarcíaHernández, M.H. Circulating MiR-146a, MiR-34a and MiR-375 in Type 2 Diabetes Patients, Pre-diabetic and Normal-glycaemic Individuals in Relation to B-cell Function, Insulin Resistance and Metabolic Parameters. Clin. Exp. Pharmacol. Physiol. 2019, 46, 1092-1100. [CrossRef]

131. Karolina, D.S.; Armugam, A.; Tavintharan, S.; Wong, M.T.K.; Lim, S.C.; Sum, C.F.; Jeyaseelan, K. MicroRNA 144 Impairs Insulin Signaling by Inhibiting the Expression of Insulin Receptor Substrate 1 in Type 2 Diabetes Mellitus. PLoS ONE 2011, 6, e22839. [CrossRef]

132. Karolina, D.S.; Tavintharan, S.; Armugam, A.; Sepramaniam, S.; Pek, S.L.T.; Wong, M.T.K.; Lim, S.C.; Sum, C.F.; Jeyaseelan, K Circulating MiRNA Profiles in Patients with Metabolic Syndrome. J. Clin. Endocrinol. Metab. 2012, 97, E2271-E2276. [CrossRef]

133. Katayama, M.; Wiklander, O.P.B.; Fritz, T.; Caidahl, K.; El-Andaloussi, S.; Zierath, J.R.; Krook, A. Circulating Exosomal MiR-20b-5p Is Elevated in Type 2 Diabetes and Could Impair Insulin Action in Human Skeletal Muscle. Diabetes 2019, 68, 515-526. [CrossRef] [PubMed]

134. Sangalli, E.; Tagliabue, E.; Sala, L.L.; Prattichizzo, F.; Uccellatore, A.; Spada, D.; Lorino, F.; de Candia, P.; Lupini, S.; Cantone, L.; et al. Circulating MicroRNA-15a Associates with Retinal Damage in Patients with Early Stage Type 2 Diabetes. Front. Endocrinol. 2020, 11, 254. [CrossRef] [PubMed]

135. Parrizas, M.; Mundet, X.; Castaño, C.; Canivell, S.; Cos, X.; Brugnara, L.; Giráldez-García, C.; Regidor, E.; Mata-Cases, M.; Franch-Nadal, J.; et al. MiR-10b and MiR-223-3p in Serum Microvesicles Signal Progression from Prediabetes to Type 2 Diabetes. J. Endocrinol. Investig. 2020, 43, 451-459. [CrossRef] [PubMed]

136. Al Kafaji, G.; Al Mahroos, G.; Alsayed, N.A.; Hasan, Z.A.; Nawaz, S.; Bakhiet, M. Peripheral Blood MicroRNA-15a Is a Potential Biomarker for Type 2 Diabetes Mellitus and Pre-Diabetes. Mol. Med. Rep. 2015, 12, 7485-7490. [CrossRef]

137. Nunez Lopez, Y.O.; Retnakaran, R.; Zinman, B.; Pratley, R.E.; Seyhan, A.A. Predicting and Understanding the Response to Short-Term Intensive Insulin Therapy in People with Early Type 2 Diabetes. Mol. Metab. 2019, 20, 63-78. [CrossRef]

138. Zhang, J.-Y.; Gong, Y.-L.; Li, C.-J.; Qi, Q.; Zhang, Q.-M.; Yu, D.-M. Circulating MiRNA Biomarkers Serve as a Fingerprint for Diabetic Atherosclerosis. Am. J. Transl. Res. 2016, 8, 2650-2658.

139. Ghorbani, S.; Mahdavi, R.; Alipoor, B.; Panahi, G.; Nasli Esfahani, E.; Razi, F.; Taghikhani, M.; Meshkani, R. Decreased Serum MicroRNA-21 Level Is Associated with Obesity in Healthy and Type 2 Diabetic Subjects. Arch. Physiol. Biochem. 2018, 124, 300-305. [CrossRef] 
140. Dias, S.; Hemmings, S.; Muller, C.; Louw, J.; Pheiffer, C. MicroRNA Expression Varies According to Glucose Tolerance, Measurement Platform, and Biological Source. BioMed Res. Int. 2017, 2017, e1080157. [CrossRef]

141. Yan, L.-N. Four-MicroRNA Signature for Detection of Type 2 Diabetes. World J. Clin. Cases 2020, 8, 1923-1931. [CrossRef]

142. Liang, Y.-Z.; Dong, J.; Zhang, J.; Wang, S.; He, Y.; Yan, Y.-X. Identification of Neuroendocrine Stress Response-Related Circulating MicroRNAs as Biomarkers for Type 2 Diabetes Mellitus and Insulin Resistance. Front. Endocrinol. 2018, 9, 132. [CrossRef]

143. Sun, K.; Chang, X.; Yin, L.; Li, J.; Zhou, T.; Zhang, C.; Chen, X. Expression and DNA Methylation Status of MicroRNA-375 in Patients with Type 2 Diabetes Mellitus. Mol. Med. Rep. 2014, 9, 967-972. [CrossRef]

144. Higuchi, C.; Nakatsuka, A.; Eguchi, J.; Teshigawara, S.; Kanzaki, M.; Katayama, A.; Yamaguchi, S.; Takahashi, N.; Murakami, K.; Ogawa, D.; et al. Identification of Circulating MiR-101, MiR-375 and MiR-802 as Biomarkers for Type 2 Diabetes. Metabolism 2015, 64, 489-497. [CrossRef]

145. Al-Muhtaresh, H.A.; Al-Kafaji, G. Evaluation of Two-Diabetes Related MicroRNAs Suitability as Earlier Blood Biomarkers for Detecting Prediabetes and Type 2 Diabetes Mellitus. J. Clin. Med. 2018, 7, 12. [CrossRef] [PubMed]

146. Li, Z.; Dong, Y.; He, C.; Pan, X.; Liu, D.; Yang, J.; Sun, L.; Chen, P.; Wang, Q. RNA-Seq Revealed Novel Non-Proliferative Retinopathy Specific Circulating MiRNAs in T2DM Patients. Front. Genet. 2019, 10, 531. [CrossRef] [PubMed]

147. Yan, S.; Wang, T.; Huang, S.; Di, Y.; Huang, Y.; Liu, X.; Luo, Z.; Han, W.; An, B. Differential Expression of MicroRNAs in Plasma of Patients with Prediabetes and Newly Diagnosed Type 2 Diabetes. Acta Diabetol. 2016, 53, 693-702. [CrossRef]

148. De Candia, P.; Spinetti, G.; Specchia, C.; Sangalli, E.; Sala, L.L.; Uccellatore, A.; Lupini, S.; Genovese, S.; Matarese, G.; Ceriello, A. A Unique Plasma MicroRNA Profile Defines Type 2 Diabetes Progression. PLoS ONE 2017, 12, e0188980. [CrossRef] [PubMed]

149. Dangwal, S.; Stratmann, B.; Bang, C.; Lorenzen, J.M.; Kumarswamy, R.; Fiedler, J.; Falk, C.S.; Scholz, C.J.; Thum, T.; Tschoepe, D. Impairment of Wound Healing in Patients with Type 2 Diabetes Mellitus Influences Circulating MicroRNA Patterns via Inflammatory Cytokines. Arterioscler. Thromb. Vasc. Biol. 2015, 35, 1480-1488. [CrossRef] [PubMed]

150. Hu, Y.; Li, Q.; Zhang, L.; Zhong, L.; Gu, M.; He, B.; Qu, Q.; Lao, Y.; Gu, K.; Zheng, B.; et al. Serum MiR-195-5p Exhibits Clinical Significance in the Diagnosis of Essential Hypertension with Type 2 Diabetes Mellitus by Targeting DRD1. Clinics 2021, 76, e2502. [CrossRef]

151. Jiang, Q.; Lyu, X.-M.; Yuan, Y.; Wang, L. Plasma MiR-21 Expression: An Indicator for the Severity of Type 2 Diabetes with Diabetic Retinopathy. Biosci. Rep. 2017, 37, BSR20160589. [CrossRef] [PubMed]

152. Wang, X.; Sundquist, J.; Zöller, B.; Memon, A.A.; Palmér, K.; Sundquist, K.; Bennet, L. Determination of 14 Circulating MicroRNAs in Swedes and Iraqis with and without Diabetes Mellitus Type 2. PLoS ONE 2014, 9, e86792. [CrossRef]

153. Dantas da Costa e Silva, M.E.; Polina, E.R.; Crispim, D.; Sbruzzi, R.C.; Lavinsky, D.; Mallmann, F.; Martinelli, N.C.; Canani, L.H.; dos Santos, K.G. Plasma Levels of MiR-29b and MiR-200b in Type 2 Diabetic Retinopathy. J. Cell. Mol. Med. 2019, 23, 1280-1287. [CrossRef]

154. Jimenez-Lucena, R.; Alcala-Diaz, J.F.; Roncero-Ramos, I.; Lopez-Moreno, J.; Camargo, A.; Gomez-Delgado, F.; Quintana-Navarro, G.M.; Vals-Delgado, C.; Rodriguez-Cantalejo, F.; Luque, R.M.; et al. MiRNAs Profile as Biomarkers of Nutritional Therapy for the Prevention of Type 2 Diabetes Mellitus: From the CORDIOPREV Study. Clin. Nutr. 2021, 40, 1028-1038. [CrossRef]

155. Santovito, D.; De Nardis, V.; Marcantonio, P.; Mandolini, C.; Paganelli, C.; Vitale, E.; Buttitta, F.; Bucci, M.; Mezzetti, A.; Consoli, A.; et al. Plasma Exosome MicroRNA Profiling Unravels a New Potential Modulator of Adiponectin Pathway in Diabetes: Effect of Glycemic Control. J. Clin. Endocrinol. Metab. 2014, 99, E1681-E1685. [CrossRef]

156. Prabu, P.; Poongothai, S.; Shanthirani, C.S.; Anjana, R.M.; Mohan, V.; Balasubramanyam, M. Altered Circulatory Levels of MiR-128, BDNF, Cortisol and Shortened Telomeres in Patients with Type 2 Diabetes and Depression. Acta Diabetol. 2020, 57, 799-807. [CrossRef]

157. Greco, M.; Chiefari, E.; Accattato, F.; Corigliano, D.M.; Arcidiacono, B.; Mirabelli, M.; Liguori, R.; Brunetti, F.S.; Pullano, S.A.; Scorcia, V.; et al. MicroRNA-1281 as a Novel Circulating Biomarker in Patients with Diabetic Retinopathy. Front. Endocrinol. 2020, 11, 528. [CrossRef]

158. Prabu, P.; Rome, S.; Sathishkumar, C.; Aravind, S.; Mahalingam, B.; Shanthirani, C.S.; Gastebois, C.; Villard, A.; Mohan, V.; Balasubramanyam, M. Circulating MiRNAs of 'Asian Indian Phenotype' Identified in Subjects with Impaired Glucose Tolerance and Patients with Type 2 Diabetes. PLoS ONE 2015, 10, e0128372. [CrossRef] [PubMed]

159. Ren, H.; Wu, C.; Shao, Y.; Liu, S.; Zhou, Y.; Wang, Q. Correlation between Serum MiR-154-5p and Urinary Albumin Excretion Rates in Patients with Type 2 Diabetes Mellitus: A Cross-Sectional Cohort Study. Front. Med. 2020, 14, 642-650. [CrossRef] [PubMed]

160. Shaker, O.G.; Abdelaleem, O.O.; Mahmoud, R.H.; Abdelghaffar, N.K.; Ahmed, T.I.; Said, O.M.; Zaki, O.M. Diagnostic and Prognostic Role of Serum MiR-20b, MiR-17-3p, HOTAIR, and MALAT1 in Diabetic Retinopathy. IUBMB Life 2018, 71, 310-320. [CrossRef]

161. Liu, H.-N.; Li, X.; Wu, N.; Tong, M.-M.; Chen, S.; Zhu, S.-S.; Qian, W.; Chen, X.-L. Serum MicroRNA-221 as a Biomarker for Diabetic Retinopathy in Patients Associated with Type 2 Diabetes. Int. J. Ophthalmol. 2018, 11, 1889-1894. [CrossRef] [PubMed]

162. Sidorkiewicz, I.; Niemira, M.; Maliszewska, K.; Erol, A.; Bielska, A.; Szalkowska, A.; Adamska-Patruno, E.; Szczerbinski, L.; Gorska, M.; Kretowski, A. Circulating MiRNAs as a Predictive Biomarker of the Progression from Prediabetes to Diabetes: Outcomes of a 5-Year Prospective Observational Study. J. Clin. Med. 2020, 9, 2184. [CrossRef]

163. Ji, H.; Yi, Q.; Chen, L.; Wong, L.; Liu, Y.; Xu, G.; Zhao, J.; Huang, T.; Li, B.; Yang, Y.; et al. Circulating MiR-3197 and MiR-2116-5p as Novel Biomarkers for Diabetic Retinopathy. Clin. Chim. Acta 2020, 501, 147-153. [CrossRef] 
164. Seleem, M.; Shabayek, M.; Ewida, H.A. MicroRNAs 342 and 450 Together with NOX-4 Activity and Their Association with Coronary Artery Disease in Diabetes. Diabetes Metab. Res. Rev. 2019, 35, e3130. [CrossRef]

165. Elemam, N.M.; Hasswan, H.; Aljaibeji, H.; Sulaiman, N. Circulating Soluble ACE2 and Upstream MicroRNA Expressions in Serum of Type 2 Diabetes Mellitus Patients. Int. J. Mol. Sci. 2021, 22, 5263. [CrossRef]

166. Pescador, N.; Pérez-Barba, M.; Ibarra, J.M.; Corbatón, A.; Martínez-Larrad, M.T.; Serrano-Ríos, M. Serum Circulating MicroRNA Profiling for Identification of Potential Type 2 Diabetes and Obesity Biomarkers. PLoS ONE 2013, 8, e77251. [CrossRef]

167. Wang, C.; Wan, S.; Yang, T.; Niu, D.; Zhang, A.; Yang, C.; Cai, J.; Wu, J.; Song, J.; Zhang, C.-Y.; et al. Increased Serum MicroRNAs Are Closely Associated with the Presence of Microvascular Complications in Type 2 Diabetes Mellitus. Sci. Rep. 2016, 6, 20032. [CrossRef]

168. Wu, L.; Dai, X.; Zhan, J.; Zhang, Y.; Zhang, H.; Zhang, H.; Zeng, S.; Xi, W. Profiling Peripheral MicroRNAs in Obesity and Type 2 Diabetes Mellitus. APMIS 2015, 123, 580-585. [CrossRef] [PubMed]

169. Yang, Z.-M.; Chen, L.-H.; Hong, M.; Chen, Y.-Y.; Yang, X.-R.; Tang, S.-M.; Yuan, Q.-F.; Chen, W.-W. Serum MicroRNA Profiling and Bioinformatics Analysis of Patients with Type 2 Diabetes Mellitus in a Chinese Population. Mol. Med. Rep. 2017, 15, 2143-2153. [CrossRef]

170. Wan, S.; Wang, J.; Wang, J.; Wu, J.; Song, J.; Zhang, C.-Y.; Zhang, C.; Wang, C.; Wang, J.-J. Increased Serum MiR-7 Is a Promising Biomarker for Type 2 Diabetes Mellitus and Its Microvascular Complications. Diabetes Res. Clin. Pract. 2017, 130, 171-179. [CrossRef]

171. Zhou, J.; Peng, R.; Li, T.; Luo, X.; Peng, H.; Zha, H.; Yin, P.; Wen, L.; Zhang, Z. A Potentially Functional Polymorphism in the Regulatory Region of Let-7a-2 Is Associated with an Increased Risk for Diabetic Nephropathy. Gene 2013, 527, 456-461. [CrossRef]

172. Feng, T.; Li, K.; Zheng, P.; Wang, Y.; Lv, Y.; Shen, L.; Chen, Y.; Xue, Z.; Li, B.; Jin, L.; et al. Weighted Gene Coexpression Network Analysis Identified MicroRNA Coexpression Modules and Related Pathways in Type 2 Diabetes Mellitus. Oxid. Med. Cell. Longev. 2019, 2019, e9567641. [CrossRef]

173. Marumo, T.; Hoshino, J.; Kawarazaki, W.; Nishimoto, M.; Ayuzawa, N.; Hirohama, D.; Yamanouchi, M.; Ubara, Y.; Okaneya, T.; Fujii, T.; et al. Methylation Pattern of Urinary DNA as a Marker of Kidney Function Decline in Diabetes. BMJ Open Diabetes Res. Care 2020, 8, e001501. [CrossRef]

174. Onishi, A.; Sugiyama, H.; Kitagawa, M.; Yamanari, T.; Tanaka, K.; Ogawa-Akiyama, A.; Kano, Y.; Mise, K.; Tanabe, K.; Morinaga, H.; et al. Urine 5MedC, a Marker of DNA Methylation, in the Progression of Chronic Kidney Disease. Dis. Markers 2019, 2019, 5432453. [CrossRef]

175. Lecamwasam, A.; Sexton-Oates, A.; Carmody, J.; Ekinci, E.I.; Dwyer, K.M.; Saffery, R. DNA Methylation Profiling of Genomic DNA Isolated from Urine in Diabetic Chronic Kidney Disease: A Pilot Study. PLoS ONE 2018, 13, e0190280. [CrossRef]

176. Fukuda, A.; Minakawa, A.; Sato, Y.; Iwakiri, T.; Iwatsubo, S.; Komatsu, H.; Kikuchi, M.; Kitamura, K.; Wiggins, R.C.; Fujimoto, S. Urinary Podocyte and TGF-B1 MRNA as Markers for Disease Activity and Progression in Anti-Glomerular Basement Membrane Nephritis. Nephrol. Dial. Transplant. 2017, 32, 1818-1830. [CrossRef] [PubMed]

177. Hishikawa, A.; Hayashi, K.; Yoshimoto, N.; Nakamichi, R.; Homma, K.; Itoh, H. DNA Damage and Expression of DNA Methylation Modulators in Urine-Derived Cells of Patients with Hypertension and Diabetes. Sci. Rep. 2020, 10, 3377. [CrossRef] [PubMed]

178. Peng, H.; Zhong, M.; Zhao, W.; Wang, C.; Zhang, J.; Liu, X.; Li, Y.; Paudel, S.D.; Wang, Q.; Lou, T. Urinary MiR-29 Correlates with Albuminuria and Carotid Intima-Media Thickness in Type 2 Diabetes Patients. PLoS ONE 2013, 8, e82607. [CrossRef]

179. Prabu, P.; Rome, S.; Sathishkumar, C.; Gastebois, C.; Meugnier, E.; Mohan, V.; Balasubramanyam, M. MicroRNAs from Urinary Extracellular Vesicles Are Non-Invasive Early Biomarkers of Diabetic Nephropathy in Type 2 Diabetes Patients with the 'Asian Indian Phenotype'. Diabetes Metab. 2018, 45, 276-285. [CrossRef]

180. Jia, Y.; Guan, M.; Zheng, Z.; Zhang, Q.; Tang, C.; Xu, W.; Xiao, Z.; Wang, L.; Xue, Y. MiRNAs in Urine Extracellular Vesicles as Predictors of Early-Stage Diabetic Nephropathy. J. Diabetes Res. 2016, 2016, e7932765. [CrossRef] [PubMed]

181. Eissa, S.; Matboli, M.; Aboushahba, R.; Bekhet, M.M.; Soliman, Y. Urinary Exosomal MicroRNA Panel Unravels Novel Biomarkers for Diagnosis of Type 2 Diabetic Kidney Disease. J. Diabetes Complicat. 2016, 30, 1585-1592. [CrossRef]

182. Eissa, S.; Matboli, M.; Bekhet, M.M. Clinical Verification of a Novel Urinary MicroRNA Panal: $133 \mathrm{~b},-342$ and -30 as Biomarkers for Diabetic Nephropathy Identified by Bioinformatics Analysis. Biomed. Pharmacother. 2016, 83, 92-99. [CrossRef] [PubMed]

183. Zhao, Y.; Shen, A.; Guo, F.; Song, Y.; Jing, N.; Ding, X.; Pan, M.; Zhang, H.; Wang, J.; Wu, L.; et al. Urinary Exosomal MiRNA-4534 as a Novel Diagnostic Biomarker for Diabetic Kidney Disease. Front. Endocrinol. 2020, 11, 590. [CrossRef]

184. Liu, Y.; Gao, G.; Yang, C.; Zhou, K.; Shen, B.; Liang, H.; Jiang, X. Stability of MiR-126 in Urine and Its Potential as a Biomarker for Renal Endothelial Injury with Diabetic Nephropathy. Int. J. Endocrinol. 2014, 2014, 393109. [CrossRef]

185. Cho, N.-J.; Kim, D.-Y.; Kwon, S.H.; Ha, T.W.; Kim, H.K.; Lee, M.R.; Chun, S.W.; Park, S.; Lee, E.; Gil, H.-W. Urinary Exosomal MicroRNA Profiling in Type 2 Diabetes Patients Taking Dipeptidyl Peptidase-4 Inhibitor Compared with Sulfonylurea. Kidney Res. Clin. Pract. 2021, 40, 383-391. [CrossRef]

186. Nishitani, S.; Parets, S.E.; Haas, B.W.; Smith, A.K. DNA Methylation Analysis from Saliva Samples for Epidemiological Studies. Epigenetics 2018, 13, 352-362. [CrossRef]

187. Sapienza, C.; Lee, J.; Powell, J.; Erinle, O.; Yafai, F.; Reichert, J.; Siraj, E.S.; Madaio, M. DNA Methylation Profiling Identifies Epigenetic Differences between Diabetes Patients with ESRD and Diabetes Patients without Nephropathy. Epigenetics 2011, 6, 20-28. [CrossRef] [PubMed]

188. Rushing, A.; Sommer, E.C.; Zhao, S.; Po'e, E.K.; Barkin, S.L. Salivary Epigenetic Biomarkers as Predictors of Emerging Childhood Obesity. BMC Med. Genet. 2020, 21, 34. [CrossRef] 
189. Al-Rawi, N.H.; Al-Marzooq, F.; Al-Nuaimi, A.S.; Hachim, M.Y.; Hamoudi, R. Salivary MicroRNA 155, 146a/b and 203: A Pilot Study for Potentially Non-Invasive Diagnostic Biomarkers of Periodontitis and Diabetes Mellitus. PLoS ONE 2020, 15, e0237004. [CrossRef] [PubMed]

190. Vlachos, I.S.; Zagganas, K.; Paraskevopoulou, M.D.; Georgakilas, G.; Karagkouni, D.; Vergoulis, T.; Dalamagas, T.; Hatzigeorgiou, A.G. DIANA-MiRPath v3.0: Deciphering MicroRNA Function with Experimental Support. Nucleic Acids Res. 2015, 43, W460-W466. [CrossRef] [PubMed]

191. Vlachos, I.S.; Paraskevopoulou, M.D.; Karagkouni, D.; Georgakilas, G.; Vergoulis, T.; Kanellos, I.; Anastasopoulos, I.-L.; Maniou, S.; Karathanou, K.; Kalfakakou, D.; et al. DIANA-TarBase v7.0: Indexing More than Half a Million Experimentally Supported MiRNA:MRNA Interactions. Nucleic Acids Res. 2015, 43, D153-D159. [CrossRef] [PubMed] 